Sub-lethal consequences of net entrapment on freshwater turtles encountered as bycatch in commercial fisheries

\author{
By \\ Lauren Joy Stoot \\ B.Sc., Lakehead University, 2011
}
A thesis submitted to the Faculty of Graduate Studies and Research in partial fulfillment of the requirements for the degree of Master of Science in Biology

Carleton University Ottawa, Ontario

(C2013, Lauren Joy Stoot 
Library and Archives

Canada

Published Heritage

Branch

395 Wellington Street

Ottawa ON K1A ON4

Canada
Bibliothèque et

Archives Canada

Direction du

Patrimoine de l'édition

395 , rue Wellington

Ottawa ON K1A ON4

Canada
Your file Votre référence

ISBN: $978-0-494-94667-1$

Our file Notre référence

ISBN: 978-0-494-94667-1
NOTICE:

The author has granted a nonexclusive license allowing Library and Archives Canada to reproduce, publish, archive, preserve, conserve, communicate to the public by telecommunication or on the Internet, loan, distrbute and sell theses worldwide, for commercial or noncommercial purposes, in microform, paper, electronic and/or any other formats.

The author retains copyright ownership and moral rights in this thesis. Neither the thesis nor substantial extracts from it may be printed or otherwise reproduced without the author's permission.
AVIS:

L'auteur a accordé une licence non exclusive permettant à la Bibliothèque et Archives Canada de reproduire, publier, archiver, sauvegarder, conserver, transmettre au public par télécommunication ou par l'Internet, prêter, distribuer et vendre des thèses partout dans le monde, à des fins commerciales ou autres, sur support microforme, papier, électronique et/ou autres formats.

L'auteur conserve la propriété du droit d'auteur et des droits moraux qui protege cette thèse. $\mathrm{Ni}$ la thèse ni des extraits substantiels de celle-ci ne doivent être imprimés ou autrement reproduits sans son autorisation.
In compliance with the Canadian Privacy Act some supporting forms may have been removed from this thesis.

While these forms may be included in the document page count, their removal does not represent any loss of content from the thesis.
Conformément à la loi canadienne sur la protection de la vie privée, quelques formulaires secondaires ont été enlevés de cette thèse.

Bien que ces formulaires aient inclus dans la pagination, il n'y aura aucun contenu manquant. 


\section{Dedication}

For my family - Mom, Dad and Rachel - thanks for providing me with endless care packages and more importantly encouragement and support along the way. 


\begin{abstract}
Freshwater bycatch is poorly documented despite the potential impact to aquatic biodiversity in a time of many other threats. As such, it is increasingly important to quantify individual consequences associated with bycatch, especially in long-lived species, where increases in adult mortality are especially likely to cause population declines. Here, I investigated the sub-lethal effects of fisheries interactions on freshwater turtles in a small-scale commercial fyke-net fishery in eastern Ontario. I experimentally exposed three frequently captured freshwater turtle species to entrapment stressors and revealed that there was evidence of physiological disturbances and behavioural impairments. Subsequently, I used fine-scale accelerometry to assess the effects of entrapment on locomotory behaviour and revealed that simulated entrapment resulted in locomotory impairment in two species over 6 hours after release. Collectively, this work will provide better insight into the sub-lethal effects associated with freshwater turtle bycatch in entrapment gear.
\end{abstract}




\section{Acknowledgments}

This thesis could not have been completed without the help and encouragement from many people. First and foremost, greatest thanks to my supervisors, Steve and Gabe, for providing me with constant support, instantaneous feedback and many opportunities throughout the past 2 years. I would also like to thank various members of the Cooke and Blouin-Demers lab. I am appreciative to all of you and thankful to call many of you good friends. My time in Ottawa, both socially and academically, would have not been the same without you. Also, my adoptive Ottawa family, the Massouds, provided me with countless family dinners, furniture and always made me feel welcome in their home - I cannot thank you enough.

For everyone that helped me in the field - Sarah Larocque, Keith Stamplecoskie and Andrew Weatherhead - thank you! Data collection would not have been possible without you! And to Nick - I couldn't have asked for a better Masters co-partner. Thanks for being a great colleague and more importantly friend over the last two years!

I would like to acknowledge the staff at Queen's University Biological Station for the use of their facilities. In addition, we would like to thank the Ontario Ministry of Natural Resources (OMNR) and Canadian Wildlife Federation (CWF) for funding. All work was conducted with Scientific Collection Permits obtained from the OMNR and Animal Care from the Canadian Council of Animal Care administered by Carleton University and Queen's University. 


\section{Co-Authorship}

\section{Chapter 2: Physiological disturbances and behavioural impairment associated with}

the incidental capture of freshwater turtles in a commercial fyke-net fishery. L.J. Stoot, N.A. Cairns, G. Blouin-Demers and S.J. Cooke

While this study is my own, the research was undertaken as part of a collaborative effort and each co-author played a valuable role in its completion. The project was conceived by Stoot, Cairns, Blouin-Demers and Cooke. Fieldwork was completed by Stoot and Cairns. All computer and data analysis was conducted by Stoot and data was interpreted by all authors. All writing was conducted by Stoot. All co-authors provided comments and feedback on the manuscript. This manuscript has been accepted by Endangered Species Research.

\section{Chapter 3: Biologgers reveal post-release behavioural impairments of freshwater turtles following fisheries interactions. L.J. Stoot, N.A. Cairns, J.D. Thiem, J.W. Brownscombe, A.J. Danylchuk, G. Blouin-Demers and S.J. Cooke}

While this study is my own, the research was undertaken as part of a collaborative effort and each co-author played a valuable role in its completion. The project was conceived by Stoot, Cairns, Blouin-Demers and Cooke. Fieldwork was completed by Stoot and Cairns, while accelerometers were provided by Danylchuk and Cooke. All computer and data analysis was conducted by Stoot. Data were interpreted by Stoot, Cairns, Brownscombe, and Thiem. All writing was conducted by Stoot. All co-authors 
provided comments and feedback on the manuscript. This manuscript is in preparation for Biological Conservation. 


\section{Table of Contents}

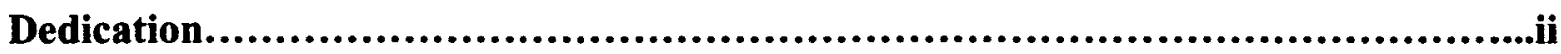

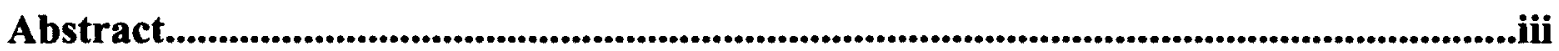

Acknowledgements..................................................................iv

Co-authorship..........................................................................v

Table of Contents...................................................................vii

List of Tables.....................................................................xi

List of Figures........................................................................

Chapter 1: General Introduction..................................................1

Research Objectives...............................................4

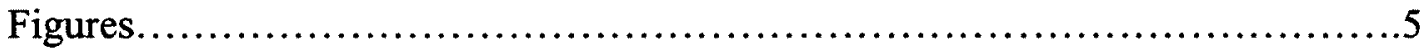

Chapter 2: Physiological disturbances and behavioural impairment associated with the incidental capture of freshwater turtles in a commercial fyke-net fishery........6

Abstract........................................................6

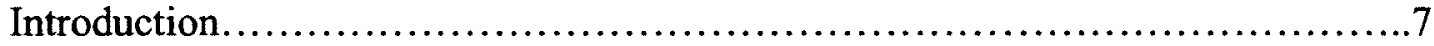

Materials and Methods................................................. 10

Results........................................................... 14

Discussion.......................................................... 16

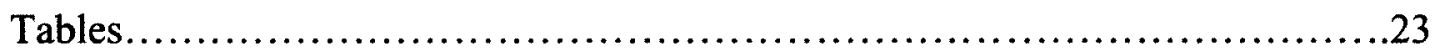

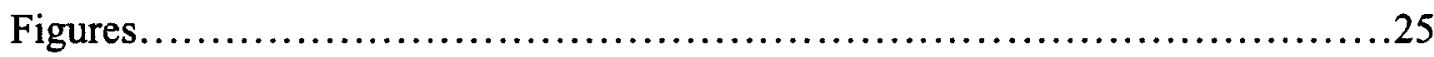

Chapter 3: Biologgers reveal post-release behavioural impairments of freshwater turtles following fisheries interactions.........................................28

Abstract.......................................................... 28

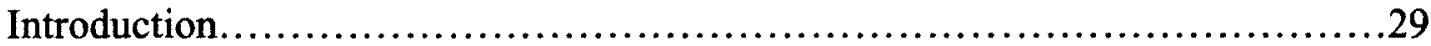

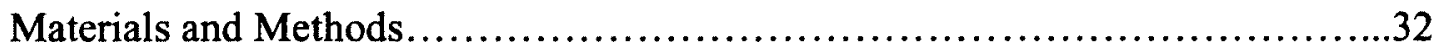

Results............................................................

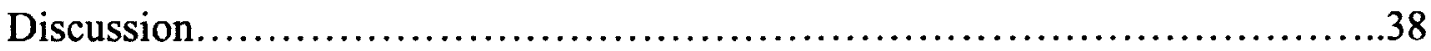

Tables...........................................................43

Figures........................................................... 47 
Chapter 4: General Discussion.....................................................51

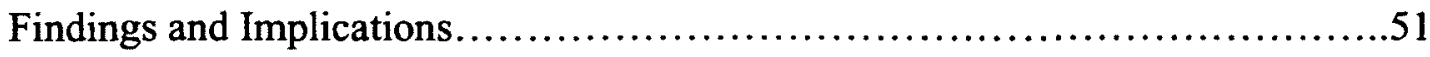

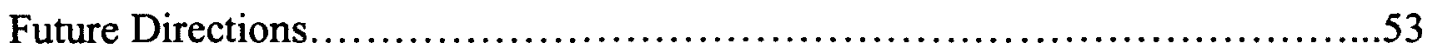

Literature Cited....................................................................55 


\section{List of Tables}

Table 2-1. Sample sizes, carapace length, and mass of three species of turtles used to assess the sub-lethal consequences of entrapment in commercial fishing nets in Lake Opinicon, Ontario, Canada.

Table 2-2. Description of the six behavioural tests, adapted from LeDain et al. (in press), that were performed on three species of turtles used to assess the sub-lethal consequences of entrapment in commercial fishing nets in Lake Opinicon, Ontario, Canada.

Table 3-1. Sample sizes, mean pair carapace length, and mean pair mass of two species of turtles used to assess the post-release of entrapment in commercial fishing nets in Lake Opinicon, Ontario, Canada.

Table 3-2. Follow-up one-way ANOVA results between experimental groups looking at 10 minute intervals over the initial first hour after release. Significant results are denoted with an asterisk (*).

Table 3-3. Follow-up one-way ANOVA results between experimental groups looking at 1 hour intervals over the initial 6 hours after release. Significant results are denoted with an asterisk $\left({ }^{*}\right)$.

Table 3-4. Follow-up one-way ANOVA results between experimental groups looking at 6 hour intervals over 48 hours after release. Significant results are denoted with an asterisk (*). 


\section{List of Figures}

Figure 1-1. Typical setting of a commercial fyke-net in eastern Ontario. Drawing reproduced from Larocque et al. $2012 \mathrm{~b}$.

Figure 2-1. Blood lactate (top) compared between species (A) and sexes (B) and $\mathrm{pH}$ (bottom) compared between species (C) and sexes (D) of control and submerged individuals. Median is reported along with the $25^{\text {th }}$ and $75^{\text {th }}$ percentiles. Bars represent the $10^{\text {th }}$ and $90^{\text {th }}$ percentiles and any outliers (black dots) are reported. Significant difference $(p<0.05)$ between control and submerged individuals are represented by asterisks $(*)$.

Figure 2-2. Behaviour Impairment Index (BII) scores after six behavioural tests of control and submerged individuals compared between species (A) and sexes of painted turtles (B). Scores range from 0 , which suggests that the individual was not impaired, to a maximum score of 1 , which indicates that the turtle was completely impaired. Median is reported along with the $25^{\text {th }}$ and $75^{\text {th }}$ percentiles. Bars represent the $10^{\text {th }}$ and $90^{\text {th }}$ percentiles and any outliers (black dots) are reported. Significant difference $(p<0.05)$ between control and submerged individuals are represented by asterisks $\left({ }^{*}\right)$.

Figure 2-3. Proportion of individuals that responded with a positive response for each behavioural test for each species; northern map turtle (Graptemys geographica; A), common musk turtle (Sternotherus odoratus; B), female painted turtle (Chrysemys picta; C) and male painted turtle (D). Black bars represent control individuals and submerged individuals in grey.

Figure 3-1. Placement of accelerometer device on left side of a tagged painted along with a radio transmitter. Arrows show direction of $\mathrm{x}, \mathrm{y}$ and $\mathrm{z}$-axis.

Figure 3-2. Least squares means of ODBA ( $y$-axis in $g$ ) over three time periods looking at eastern musk turtles (Sternotherus odoratus; top) and painted turtles (Chrysemys picta; bottom) over three time periods; 1st hour post-release (A \& B), 6 hours post-release (C \& $D)$ and 48 hours post-release (E \& F). Control individuals (black circles) are compared to submerged individuals (white circles) with error bars representing standard error. Significant follow-up one-way ANOVAs are denoted with an asterisk $\left(^{*}\right)$. Note: $y$-axis differs between species.

Figure 3-3. Behaviour Impairment Index (BII) scores after six behavioural tests of control and net submerged individuals compared between species. Scores range from 0 , which suggests that the individual was not impaired, to a maximum score of 1 , which indicates that the turtle was completely impaired. Median is reported along with the $25^{\text {th }}$ and $75^{\text {th }}$ percentiles. Significant difference $(p<0.05)$ between control and submerged individuals are represented by asterisks $(*)$. 
Figure 3-4. Proportion of individuals that responded with a positive response for each behavioural test for each species; eastern musk turtles (Sternotherus odoratus; left) and painted turtle (Chrysemys picta; right). Black bars represent control individuals and submerged individuals in grey. 


\section{Chapter 1: General Introduction}

Commercial fisheries in marine and freshwater ecosystems exploit mostly fish and crustaceans for human benefit. Commercial fisheries collectively account for approximately 92 million metric tonnes of global landings (FAO 2009). Although the majority of catches consist of targeted species, an estimated 7.3 metric tonnes caught in marine fisheries (or $8 \%$ ) are non-targeted organisms (Kelleher 2005). The capture of non-targeted species is known as bycatch and can include non-targeted fish, birds, mammals, and reptiles (Crowder \& Murawski 1998; Hall et al. 2000). Bycatch occurs in long-line, trawl, and gill net fisheries. Recently, greater efforts have been deployed to quantify and prevent bycatch, although most efforts have been directed towards marine ecosystems with relatively little research devoted to freshwater (Allen et al. 2005; Raby et al. 2011). Lack of research in freshwater fisheries is concerning due to high extinction rates suffered by freshwater species along with the abundance of at risk bycatch species in freshwater (Riccardi \& Rasmussen 1999; Dudgeon et al. 2006).

Bycatch can result in a variety of consequences and effects. Immediate mortality, such as in-net or on-hook mortality, has been reported in several frequently caught bycatch species including a variety of fish as well as marine mammals, sea birds, sharks, and marine turtles (e.g., Julian \& Beeson 1998; Lewison et al. 2004; Zeeberg et al. 2006; Moore et al. 2008; Alfaro-Shigueto et al. 2011; Finkbeiner et al. 2011). Captured individuals are exposed to a wide range of injury and stressors from interacting with fishing gear (Davis 2002; Skomal 2007). Injuries may include abrasion and tissue damage from hooks and netting material (e.g., Aguilar et al. 1995; Lewison et al. 2004). Stressors can include confinement, exhaustion (from struggling), and for air breathing 
species, inability to access oxygen (e.g., Hoopes et al. 2000; Snoddy et al. 2008). These stressors can cause immediate effects which can impair behaviour such as foraging ability or predator avoidance.

Although immediate mortality is a major concern, the presence of sub-lethal effects and post-release mortality can also have important population consequences. Furthermore, even if animals survive bycatch, their long-term condition (e.g., growth), health, and fitness may be altered. For that reason, the Species at Risk Act in Canada (2002, c.29, s.32) defines that it is illegal to kill, harm, harass, capture, or take any endangered or threatened species. Clearly, harm and harass fall within the category of sub-lethal effects emphasizing the need to not just document mortality, but to also understand what activities contribute to harm or harassment. Physiological and behavioural endpoints provide objective and ecologically relevant measures of harm and harassment.

Bycatch of marine mega-fauna, such as turtles, is especially concerning as they are long-lived and have delayed sexual maturity. Consequently, even slight increases in adult mortality, from sources such as bycatch, have the potential to causes population declines (Congdon et al. 1993; 1994). Freshwater turtles have similar life history traits, making them equally susceptible to population declines even with low levels of adult mortality. In eastern Ontario, a small-scale fyke net fishery exists on inland freshwater lakes and rivers. This fishery is a typical small-scale fishery employing approximately 50 fishers that use relatively small fishing vessels and collect fish mainly for local consumption. Target species include sunfish (Lepomis spp.) primarily although bullhead 
(Ameiurus spp.), perch (Perca flavescens), black crappie (Pomoxis nigromaculatus), and rock bass (Ambloplites rupestris) are also harvested (Burns 2007; Larocque et al. 2012a). Fyke-nets are typically set in tandem with a lead line connecting each mouth (Fig. 1-1). Although fishing regulations state that the season is open from ice off in the early spring until ice-on in the fall, most fishers prefer to work in early spring or fall. Quantity of nets varies depending on area and license issued to each fisher, but some individuals are allowed to deploy up to 80 fyke-nets at once (Burns 2007). Habitats of freshwater turtles and commercial fish often overlap, thus increasing the possibility of turtle entrapment. Previous studies have confirmed that entrapment in fishing nets as a threat to freshwater turtles (Barko et al. 2004; Carrière et al. 2007; McClellan \& Read 2009; Echwikhi et al, 2011; Larocque et al. 2012ab). Depending on the season, typical setting of commercial fyke-nets does not require regular monitoring or provision of air spaces (Burns 2007), and as a result turtles that are caught often drown (Larocque et al. 2012b). Even low levels of anthropogenic mortality are problematic for freshwater turtles given their lifehistory characteristics and the fact that many populations are in decline from a variety of threats including boat strikes, vehicle collisions, and habitat loss/alteration (Gibbons et al. 2000). Currently, the Committee on the Status of Endangered Wildlife in Canada (COSEWIC) lists seven of eight turtle species present in Ontario as species at risk. Of these at-risk species, three are most likely to interact with commercial fishing gear: the eastern musk turtle (Sternotherus odoratus) designated as threatened, and the northern map turtle (Graptemys geographica) and common snapping turtle (Chelydra serpentina) both recognized as special concern. Painted turtles (Chrysemys picta) are also likely to interact with commercial fishing gear. 


\section{Research Objectives}

The overall objective of my thesis was to provide insight into the sub-lethal effects of fisheries interactions on freshwater turtles. The eastern Ontario commercial fyke-net fishery was used as a study system given concern among natural resource managers regarding the effects of bycatch on turtle populations. In Chapter 2, I investigated the acute physiological consequences associated with incidental capture of freshwater turtles in fishing nets using an experimental approach. In addition, a secondary objective of Chapter 2 was to test for differences in responses to entrapment between sexes using painted turtles (Chrysemys picta) as a model. In Chapter 3, I investigated the sub-lethal effects associated with turtle bycatch using novel tri-axial accelerometers to monitor movement behaviour following release. Understanding both the immediate and postrelease sub-lethal consequences related to turtle bycatch is important in determining potential post-release mortality or otherwise contribute to changes in turtle condition, health or fitness that may have significant population consequences. 
Figures

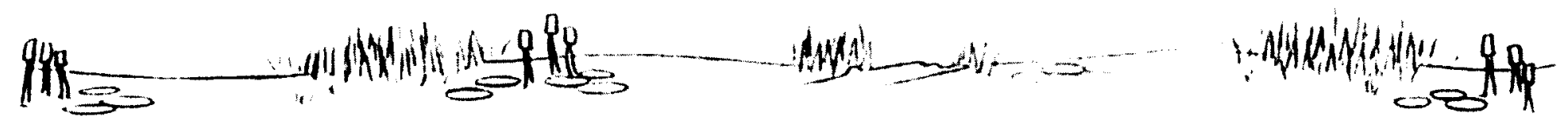

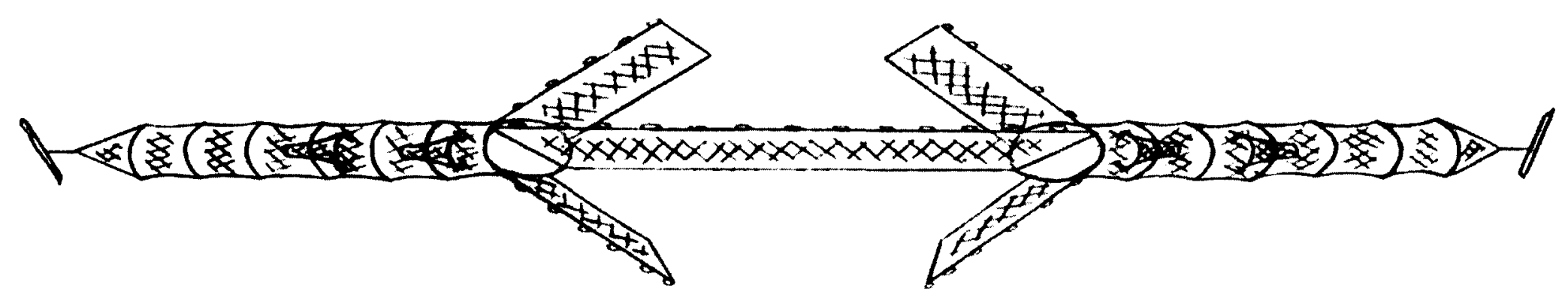

Figure 1-1. Typical setting of a commercial fyke-net in eastern Ontario. Drawing reproduced from Larocque et al. $2012 \mathrm{~b}$. 


\title{
Chapter 2: Physiological disturbances and behavioural impairment associated with incidental capture of freshwater turtles in a commercial fyke-net fishery
}

\begin{abstract}
\end{abstract}
Turtles are caught as bycatch in commercial fisheries in both inland and marine waters. Turtle mortality associated with bycatch is concerning as life-history characteristics of turtles, including high juvenile mortality and delayed sexual maturity, make them particularly susceptible to population declines following small increases in adult mortality. In eastern Ontario, freshwater turtles are encountered as bycatch in an inland commercial fyke-net fishery. Although some temperate turtle species can tolerate prolonged submergence, their ability to withstand submergence decreases as water temperatures increase such that turtles may experience severe physiological disturbances and mortality following prolonged forced submergence. The purpose of my study was to evaluate the sublethal physiological consequences and related behavioural impairments associated with fyke-net capture for three species of freshwater turtles (eastern musk turtle; Sternotherus odoratus, northern map turtle; Graptemys geographica, and painted turtle; Chrysemys picta). Individuals that were entrapped for 3 hours at elevated water temperatures $\left(23-29^{\circ} \mathrm{C}\right)$ displayed considerably higher blood lactate and lower blood $\mathrm{pH}$ compared to free-living individuals. This trend was consistent across species and sexes. Both map and painted turtles displayed low responsiveness to behavioural assessments following entrapment, but musk turtles did not exhibit behavioural impairment from entrapment, despite having the largest increase in blood lactate. Sub-lethal responses can be used to identify potential harm or fitness impacts even in the absence of immediate mortality, which is important for protected species. 


\section{Introduction}

Bycatch, the capture of non-targeted species, frequently occurs in commercial fisheries (Crowder \& Murawski 1998; Hall et al. 2000; Hall \& Mainprize 2005). Bycatch of marine species, especially turtles, has attracted considerable scientific and media attention (Lewison et al. 2004; Wallace et al. 2010). A variety of marine turtle bycatch reduction strategies have been developed and tested (UN FAO 2009) such as the turtle excluder device, which has prevented the accidental capture of turtles in the shrimp trawl fishery (Seidel \& McVea 1982). Despite being less well documented (Raby et al. 2011), bycatch of freshwater turtles also occurs in a variety of inland fisheries (Barko et al. 2004; Carrière et al. 2009; McClellan et al. 2009; Larocque et al. 2012a). Turtles typically exhibit high juvenile morality and delayed sexual maturity (Congdon $e t$ al. 1993). Thus slight increases in adult mortality, from sources such as bycatch, have the potential to cause population declines (Congdon et al. 1993; Gibbons et al. 2000). This is particularly concerning given the at-risk status of many marine and freshwater turtles (Burke et al. 2000).

Interactions with fishing gear can cause stress and injuries that alter the health, condition, behaviour, and potentially the survival of animals, something well studied in fish (e.g., Chopin \& Arimoto 1995; Davis 2002). These interactions have been comparatively poorly studied (aside from immediate mortality) in other taxa such as mammals, birds, and reptiles, including marine turtles. Air breathing organisms are at particular risk of bycatch-related stress and mortality as a result of entrapment and entanglement in fishing gear that impedes their ability to reach the water surface and respire. The capacity to withstand the effects of submergence will dictate the likelihood 
of mortality for a given species following capture in commercial fishing nets. Many freshwater turtle species can spend extended periods submerged. Some species, such as painted turtles (Chrysemys picta), are able to remain submerged with little to no oxygen for extensive periods during hibernation (Belkin 1963; Gatten 1981; Milton \& Prentice 2007). In addition to reduced metabolic rate during submergence, painted turtles rely on anaerobic metabolism to further reduce oxygen requirements (Jackson 2000a). The mechanisms and ability to withstand low oxygen for prolonged periods is species-specific (Reese et al. 2001). For instance, some species have a better ability to sequester $\mathrm{CO}_{2}$ : painted turtles appear to be one of the most proficient species that is able to tolerate extensive periods in true anoxic conditions by using carbonate from their shells to buffer blood acidosis (Ultsch 1989; Ultsch \& Jackson 1995; Jackson 2000a). Another mechanism frequently used by some turtles to acquire oxygen is the use of extrapulmonary gas exchange (e.g., eastern musk turtle; Ultsch et al. 1984; Ultsch \& Cochran 1994). Individuals use their highly vascularized skin lining the cloaca and buccopharynx cavity to obtain oxygen from water (Feder \& Burggren 1985; Ultsch 1988; Stone et al. 1992). Collectively, these mechanisms all contribute to a turtle's ability to withstand submergence associated with incidental capture.

For freshwater turtles, prolonged entrapment within nets is most likely stressful, particularly when water temperature is elevated (Fratto et al. 2008; Larocque 2012b). Elevated water temperatures and ensuing increased metabolic rates reduce the length of time a turtle can cope with submergence (Musacchia 1959; Herbert \& Jackson 1985; Ultsch 1989). In addition, as water temperatures increase, dissolved water oxygen levels decrease, thus limiting the available oxygen for uptake. This can result in rapid lactate 
accumulation even for species capable of extrapulmonary gas exchange (Frankel et al. 1966; Dejours 1994). Finally, entrapment exposes turtles to a variety of additional stressors, in particular the exertion associated with trying to escape from nets and interactions with other species, both target and bycatch, in a confined area.

The objective of our study was to assess the sub-lethal consequences of fyke-net entrapment on three species of freshwater turtles. In particular, we evaluated blood lactate and $\mathrm{pH}$, as well as behavioural responsiveness following experimental entrapment. We also evaluated whether male and female painted turtles differed in their physiological and behavioural responses to entrapment. We focused on freshwater turtles that are incidentally captured in a small-scale commercial fyke-net fishery in eastern Ontario (Carrière et al. 2009; Larocque et al. 2012ab). Upon capture, fishers are required to discard turtles (whether alive or dead) along with other bycatch (e.g., gamefish) as soon as possible after landing. Commercial fishing in that region occurs on inland lakes and rivers, with sunfish (Lepomis spp.) being the primary targeted species, in addition to bullhead (Ameiurus spp.), yellow perch (Perca flavescens), black crappie (Pomoxis nigromaculatus), and rock bass (Ambloplites rupestris; Burns 2007; Larocque et al. 2012a). The habitats of freshwater turtles and targeted commercial fish overlap, thus increasing the possibility of turtle entrapment (Carrière et al. 2009; McClellan \& Read 2009; Larocque et al. 2012a). Presently, the Committee on the Status of Endangered Wildlife in Canada (COSEWIC) lists seven of the eight turtle species present in Ontario as species at-risk. Of these seven at-risk species, two are most likely to interact with commercial fishing gear and hence were the focus of our study: the eastern musk turtle (Sternotherus odoratus) and the northern map turtle (Graptemys geographica) are both 
recognized as Special Concern. In addition, the non-threatened painted turtle (Chrysemys picta) was used as a model as it is the most commonly captured species in this fishery.

\section{Materials and methods}

Study area

We conducted the study on Lake Opinicon ( $\left.44^{\circ} 34^{\prime} \mathrm{N}, 76^{\circ} 19^{\prime} \mathrm{W}\right)$ approximately $100 \mathrm{~km}$ southwest of Ottawa, Ontario, Canada. Experiments were conducted between 30 June and 28 July 2011 when water temperatures ranged from 23 to $29^{\circ} \mathrm{C}$. Free-living control turtles were captured between 14 June and 17 September 2011 when water temperatures ranged from 19 to $28^{\circ} \mathrm{C}$ and between 29 May and 3 June 2012 when water temperatures ranged from 20 to $25^{\circ} \mathrm{C}$. For all experiments dissolved oxygen was at or near saturation (e.g., 6-8 $\mathrm{mg} \cdot \mathrm{l}^{-1}$ ).

Fyke-nets

We used fyke-nets similar to the ones used in the local commercial fishery to collect turtles following the methods outlined in Larocque et al. (2012a). Nets were fished in pairs and were attached by leads (see Fig. 1 in Larocque et al. 2012a). Each net contained seven steel hoops, which were $0.5 \mathrm{~m}$ apart and measured $0.9 \mathrm{~m}$ in diameter, and two throats were located in the second and fourth hoop. Two wings and a lead were attached vertically to the mouth of each net. Wings measured $4.6 \mathrm{~m}$ long by $0.9 \mathrm{~m}$ high while each lead measured $10.7 \mathrm{~m}$ long by $0.9 \mathrm{~m}$ high. All gear was fabricated with 2.54 cm square, $5.08 \mathrm{~cm}$ stretch, nylon mesh. 
Experimental procedure

For this experiment, we used 73 turtles of 3 different species for both treatment and control (see Table 1). We used painted turtles to test for sex-specific differences despite an approximately equal sex-capture ratio of $1: 1$ to minimize any potential sublethal effects on females. Indeed, that was a condition of our Scientific Collection Permit and Species-at-Risk Permit from the Ontario Ministry of Natural Resources. We used two groups to determine the physiological effects and behavioural impairments associated with entrapment in fyke-nets: a treatment group in which turtles were submerged in a fyke-net for $3 \mathrm{hrs,} \mathrm{and} \mathrm{a} \mathrm{control} \mathrm{group} \mathrm{of} \mathrm{free-living} \mathrm{turtles.} \mathrm{This}$ submergence time was chosen to provide sufficient time for blood physiology to respond to capture stress while avoiding immediate mortality (Larocque et al. 2012b). It should be noted that our treatment length of $3 \mathrm{hrs}$ is not representative of typical entrapment length within the commercial fishery in Ontario, as fishers are required to check their nets every 2 to 7 days, depending on the season. Our estimates of physiological disturbance are therefore very conservative.

Control turtles were "free-living" individuals which were caught via dip-net or snorkelling and sampled immediately (within 3 minutes of capture) to obtain baseline blood physiology values and behaviour tests. Turtles were transported back to the laboratory for morphometric measurements. Turtles were held outdoors in $\sim 700 \mathrm{~L}$ fibreglass tanks at ambient temperatures until they could be returned to capture location. Tanks were supplied with lake water using a flow though system and turtles were not fed, but were provided with basking platforms and exposed to ambient sunlight. 
Treatment individuals were collected initially by fyke-nets equipped with floats, which were checked daily and captured turtles were transported back to the lab to obtain morphometric measurements. Turtles were held in outdoor $\sim 700 \mathrm{~L}$ fibreglass tanks at ambient temperature for a minimum of $48 \mathrm{~h}$ before experimental trials to eliminate any potential effects of initial capture stress. After a minimum of 48 hours, individuals were subjected to simulated entrapment for 3 hours using a fyke-net that was modified to prevent escape or entry. The net was completely submerged in the lake in approximately $1.5 \mathrm{~m}$ of water which ranged from 23 to $29^{\circ} \mathrm{C}$ over the course of this experiment.

\section{Blood physiology}

All blood samples were taken within 3 minutes of removal from net or of capture. Approximately $0.5 \mathrm{ml}$ of blood was taken from the caudal vasculature on the dorsal portion of the tail using a $1 \mathrm{ml}$ Tuberculin slip tip with a sodium-heparinized $(10000$ USP units $\mathrm{ml}^{-1}$, Sandoz, Québec, Canada) coated syringe with a 25 gauge, $38 \mathrm{~mm}$ needle for painted and map turtles (Becton Dickinson and Company, Franklin Lakes, New Jersey). Smaller 28.5 gauge needles and syringes were used for musk turtles (Becton Dickinson and Company, Franklin Lakes, New Jersey). Blood lactate was measured immediately after collection using a Lactate Pro ${ }^{\mathrm{TM}}$ meter (Arkray Inc., Japan) that was previously validated with teleost fish (Brown et al. 2008). Remaining blood was transported back to the field laboratory in the syringe on ice in a cooler. Blood pH was measured using a field physiology meter within 2 hours of collection with a 3-point calibrated minilab IQ128 Elite pH meter (IQ Scientific Instruments Inc., California) at ambient temperature. 


\section{Behavioural assessments}

Both experimental and control groups were tested for behavioural responses. Involuntary response to a variety of stimuli such as touch, gravity, and sound can be helpful in predicting mortality. These assessments to predict mortality have been used on a variety of vertebrates (Davis 2007; 2010), including freshwater turtles (LeDain et al. in press). We used six behavioural tests, similar to the ones employed by LeDain et al. (in press) that included escape ability, righting ability (both on land and in water), response to startles (audible/pressure and visual), and tactile stimuli to the head, limbs and tail (Table 2-2). The ability of turtles to complete these tests can serve as indicators of their condition. We combined tactile stimuli into a single response, as there was no variation between the reactions to head and limb/tail stimuli. If the individual responded to the stimulus, the test was scored as present; lack of reaction indicated an absent response. Each test was scored as present (1) or absent ( 0 ) and converted into a Behaviour Impairment Index (BII) which is an overall score of impairment for each individual based on the number of tests performed where BII $=1-($ sum of individual test scores/total possible score of 6 ). The BII ranges from 0 , which indicates that the individual was not impaired, to a maximum score of 1 , which indicates that the turtle was completely impaired.

\section{Statistical analyses}

We compared blood lactate and $\mathrm{pH}$ levels of control and treatment groups between male turtles of three species. Blood lactate and $\mathrm{pH}$ residuals did not violate the assumptions of normality and homogeneity of variance, therefore we used a two-way 
ANOVA to test the effect of species and group on blood lactate and $\mathrm{pH}$. To assess whether control and experimental groups differed within a species, we used follow-up two sample t-tests that assumed unequal variance. We also evaluated physiological differences between males and females in painted turtles from control and treatment groups. Both blood lactate and $\mathrm{pH}$ residuals did not violate the assumptions of normality and homogeneity of variance, therefore we used a two-way ANOVA to test the effect of species and group on BII. Behavioural data were also analyzed using a two-way ANOVA since BII score residuals did not violate the assumptions of normality and homogeneity of variance. We again used follow-up two-sample t-tests that assumed unequal variance to assess whether control and experimental groups differed within each species. All statistical tests were performed using JMP (Version 9.0.1, SAS Institute). Significance was accepted at $\alpha<0.05$.

\section{Results}

Of the 73 individuals sampled, all were able to complete the trial and no turtles died. Our test of the physiological effects of entrapment in males of three species revealed a significant interaction between species and experimental group for blood lactate (Partial $\left.\mathrm{R}^{2}=0.02, F_{(2,48)}=14.19, p<0.001\right)$ and marginally significant for blood $\mathrm{pH}\left(\right.$ Partial $\left.\mathrm{R}^{2}=0.01, F_{(2,48)}=3.18, p=0.051\right)$. These interactions indicate that the effect of treatment on blood lactate and $\mathrm{pH}$ differs by species. Post-hoc two sample t-tests revealed that blood lactate was significantly higher in treatment than in control groups in all three species: map turtles $\left.\left(t_{(17}\right)=18.82, p<0.001\right)$, musk turtles $\left(t_{(9)}=20.81, p<\right.$ $0.001)$, and painted turtles $\left(t_{(11)}=16.39, p<0.001\right.$; Fig. 2-1). Accordingly, blood pH was also lower in treatment groups than in control groups in all three species: map turtles $\left(t_{(13)}\right.$ 
$=9.684, p<0.001)$, musk turtles $\left(t_{(16)}=17.313, p<0.001\right)$, and painted turtles $\left(t_{(8)}=\right.$ 10.82, $p<0.001$; Fig. 2-1). Significant interactions resulted from musk and painted turtles having marked increases in blood lactate and decreases in $\mathrm{pH}$ between control and treatment groups, while map turtles exhibited less dramatic differences (Fig. 2-1).

We investigated behavioural impairment associated with entrapment in males of three species. There was a significant interaction between species and experimental group for the behavioural scores (Partial $\mathrm{R}^{2}=0.16, F_{(2,48)}=14.07, p<0.001$ ), indicating that the three species were not impaired to the same extent. Post-hoc two sample t-tests revealed that the BII scores were significantly different between control and treatment groups for map turtles $\left(t_{(9)}=6.8206, p<0.001\right)$, and painted turtles $\left(t_{(12)}=4.8179, p<0.001\right)$, but there was no significant difference in musk turtles $\left(t_{(9)}=1, p=0.3434\right.$; Fig. 2-2).

When we investigated sex differences in physiological responses to entrapment in painted turtles, there were no significant sex by group interactions for blood lactate $\left(\right.$ Partial $\left.\mathrm{R}^{2}<0.001, F_{(1.31)}=0.05, p=0.83\right)$ or blood pH (Partial $\mathrm{R}^{2}=0.01, F_{(1,31)}=3.76$, $p=0.062$ ). In addition, there was no significant difference between males and females in blood lactate (Partial $\left.\mathrm{R}^{2}<0.001, F_{(1,31)}=0.09, p=0.77\right)$ or blood $\mathrm{pH}\left(\right.$ Partial $\mathrm{R}^{2}<0.001$ $F_{(1,31)}=0.07, p=0.79$, Fig. $\left.2-1\right)$. There was a significant difference between painted turtle control and submerged groups when combining both sexes in both blood lactate $\left(\right.$ Partial $\left.\mathrm{R}^{2}=0.94, F_{(1,31)}=809.95, p<0.001\right)$ and blood pH $\left(\right.$ Partial $\mathrm{R}^{2}=0.91, F_{(1,31)}=$ 336.37, $p<0.001$; Fig. 2-1).

BII scores between male and female painted turtles also lacked a sex by group interaction (Partial $\left.\mathrm{R}^{2}<0.001, F_{(1.31)}=0.014, p=0.906\right)$. In addition, there was no 
significant difference between males and females (Partial $\mathbf{R}^{2}<0.001, F_{(1,31)}=0.027, p=$ 0.871; Fig. 2-2). There was a significant difference between painted turtle control and submerged group behaviour scores (Partial $\mathrm{R}^{2}=0.57, F_{(1,31)}=43.18, p<0.0001$; Fig. 2 2).

\section{Discussion}

Our main objective was to determine the sub-lethal consequences of fyke-net entrapment on three species of freshwater turtles. It was evident that simulated incidental capture causes significant changes to blood physiology compared to free-living individuals in all three species. Although the literature lacks baseline blood physiology values for musk and map turtles at temperatures similar to our study, all three species displayed control values similar to baseline blood lactate $\left(\sim 1.5 \mathrm{mmol}^{-1}\right)$ and $\mathrm{pH}(\sim 7.8)$ found in painted turtles at similar temperatures to our study $\left(\sim 22^{\circ} \mathrm{C}\right.$; Keiver et al. 1992ab; Warren \& Jackson 2004). Blood lactate and $\mathrm{pH}$ trends associated with submergence were similar to trends found by Larocque et al. (2012b) where research focused on painted turtles submerged for 4 hours. Clearly, treatment turtles in our experiment experienced stress related to prolonged forced submergence. Submergence of painted turtles for 12 hours in small cages that prevented extensive movements also resulted in similarly higher blood lactate and lower $\mathrm{pH}$ values to those we found (Fig. 2-1; LeDain et al. in press). Entrapment in nets has the potential to cause exhaustion more rapidly in turtles as a result of the ability to move within the net and the active attempts to escape (Larocque et al. 2012b). All three species displayed a decline of 0.7 or greater in blood $\mathrm{pH}$ between control and treatment groups (Fig. 2-1). Decline in blood pH of approximately one unit can be lethal for the freshwater turtles assessed in this study (Ultsch et al. 1984). In 
addition, lactate values of entrapped turtles were similar to those found in hibernating painted turtles after 100-150 days (approximately $20-25 \mathrm{mmol}^{-1}$ Reese et al. 2004) at $3^{\circ} \mathrm{C}$ despite entrapment for only $3 \mathrm{hrs}$. Additionally, increased rate and intensity of movement in the net as a result of warmer temperatures, would result in a higher rate of oxygen consumption, therefore increasing acidosis (Robin et al. 1964; Jackson \& Silverblatt 1974; Herbert \& Jackson 1985). These findings agree with previous research that suggests that water temperature, regardless of the oxygen content, can limit duration of survival (Ultsch 1989). Similar studies have assessed the physiological effects of various types of fishing gear, such as trawl nets (Stabenau et al. 1991; Harms et al. 2003) and gillnets (Snoddy et al. 2009) on blood physiology of marine turtles and have shown similar effects of entrapment on blood physiology as our study.

Fyke-net entrapment and associated submergence led to species-specific physiological responses, pointing to the potential danger of using a single model species as a surrogate for the various species potentially captured as bycatch (Fig. 2-1). Painted turtles exhibited a physiological response typical of a non-bimodally breathing turtle which relies on extreme anoxia tolerance. Denial of oxygen stimulates a physiological switch to anaerobic metabolism, which is characterized by the accumulation of blood lactate and decline in blood pH (Jackson 2000b). Despite having the ability to tolerate true anoxia in cold water, when submerged in elevated normoxic conditions (such as in this study), painted turtles were unable to acquire sufficient oxygen through secondary gas exchange mechanisms to remain aerobic (Ultsch \& Jackson 1982; Jackson et al. 2000; Reese et al. 2001) as indicated in our study by elevated blood lactate and reduced blood $\mathrm{pH}$. Therefore, painted turtles must metabolize energy anaerobically resulting in 
blood acidosis (Ultsch \& Jackson 1982; Ultsch et al. 1999; Jackson et al. 2000; Reese et al. 2001). Another mechanism of tolerating submergence is the use of gas exchange via extra pulmonary oxygen uptake or bimodal respiration, which is typified by musk and map turtles (Ultsch et al. 1984; Reese et al. 2001). Both species are known to be generally intolerant of prolonged submergence in anoxic conditions, but can survive extended periods of submergence in normoxic conditions during hibernation by remaining aerobic while accumulating relatively little blood lactate (Reese et al. 2001; Reese et al. 2003). Despite their tolerance of submergence in normoxic conditions, lactate accumulation in both species over 3 hours was relatively high in our study (Fig. 21A). We observed turtles swimming within the net and actively searching for exits. Increased activity, exacerbated by the elevated temperature could be also contributing to the observed increase in blood lactate and decline in pH (Dejours 1994). Gatten (1984) compared free-diving and forcibly submerged loggerhead musk turtles (Sternotherus minor) and found that involuntary submergence led to altered physiology and behaviour, including the accumulation of lactate. Stress associated with forced submergence may to some extent inhibit turtles from buffering acidosis, therefore altering associated blood physiology.

Furthermore, behavioural tests support our contention that the responses to simulated capture are species-specific. BII scores of submerged individuals were significantly lower than those of control in painted and map turtles (Fig. 2-2). This indicates that physiological stress associated with submergence is manifested in behavioural impairments, such as righting ability (Fig. 2-3). Interestingly, map turtles had the smallest percent increase in lactate and decrease in $\mathrm{pH}$, despite being the most 
behaviourally impaired species. This is not unexpected as map turtles are known for their poor ability to tolerate blood acidosis (Reese et al. 2001). These results point to a speciesspecific sensitivity and some incongruence between blood physiology and behavioural indicators, again outlining the potential danger of relying on data from a single species to make management recommendations. Surprisingly, musk turtles did not have significantly different BII scores between control and treatment groups despite having significantly different blood physiology values. Out of the six reflex tests, the behaviour was present for all individuals from control and treatment groups for five of the tests (Fig. 2-3). Their ability to obtain oxygen from normoxic water (Ultsch et al. 1984) could account for their behavioural responsiveness, although we would expect to see corresponding physiological results. While accumulation of lactate occurs rather quickly, studies have shown that it takes several hours for lactate to be metabolized (Bennett 1978; Seymour 1982). Quick accumulation and potential lag time in metabolizing lactate could account for incongruence between blood physiology and behavioural responses. Increased activity as a result of elevated temperature could result in increased lactate levels and decreased $\mathrm{pH}$, but our behavioural results do not support this idea. Compared to fish, where there are several examples of incongruence between physiological and reflex (including some behaviours) metrics associated with fisheries interactions (Davis et al. 2001; Thompson et al. 2008), there are no published examples that have evaluated both types of endpoints in freshwater turtles to determine whether our observations are unique.

Sex appeared to have no influence on physiological or behavioural impairment following submergence in painted turtles as similar responses were seen in males and 
females (Fig. 2-1 and 2-2). Significant differences were seen in blood lactate and $\mathrm{pH}$ as well as BII scores between both control and submerged turtles in both sexes. Some studies investigating normal blood physiology profiles for various turtle species (e.g., Chelonia mydas, Podocnemis expanssa) have determined that males and females have similar physiological profiles at rest (Bolten \& Bjorndal 1992; Oliveira-Júnior et al. 2009). Alternatively, some studies suggest significant differences in hematology between sexes, including the New Guinea snapping turtles (Elseya novaequineae; Anderson et al. 1997), bog turtles (Clemmys muhlenbergii; Brenner et al. 2002), and Mediterranean pond turtle (Mauremys leprosa; Hidalgo-Vila et al. 2007). Because turtles are ectotherms, "normal" values can vary as a result of many factors such as activity, temperature, and seasonality. Understanding potential sex-specific fitness consequences is important in slow-maturing, long-lived species where females are more ecologically important than males. Other species should be investigated to determine if this pattern is consistent (including across sexually dimorphic or imperiled species) as the use of surrogates is clearly not ideal.

Although freshwater turtles are particularly adept at tolerating submergence, I found that incidental capture causes significant species-specific changes in physiology and can lead to behavioural impairments. These changes in blood physiology were seen despite a submergence period much shorter than typically occurs in the commercial fishery in eastern Ontario. Despite lack of immediate mortality, some species exhibited behavioural impairments, which would compromise their activity and potentially result in post-release mortality, such as drowning. Additional non-lethal consequences associated with submergence are currently unknown, and should be the focus of future research. Our 
findings point to intrinsic differences in blood physiology and behaviour among species and reflect the need for management decisions to account for inter-specific variation. Painted turtles have previously been used as surrogates for at-risk species in the eastern Ontario fyke-net fishery (Larocque et al. 2012b). Our study highlights the limitations of using a surrogate species to gauge the physiological response to incidental capture. The use of a conservative approach with safe and pre-determined endpoints allowed us to determine the effects of incidental capture on two additional at-risk turtle species. Although mortality is an ecologically relevant endpoint for studying the effects of bycatch in an experimental context, it is not ethically appropriate when studying at-risk animals (Putman 1995; Minteer \& Collins 2005). Sub-lethal consequences, such as physiological disturbance and behavioural impairments are becoming recognized as useful and relevant tools in conservation science (Wikelski \& Cooke 2006; Cooke et al. in press a). In particular, physiological (e.g., Davis 2002; Cooke et al. in press b) and reflex (e.g., Davis 2010) endpoints serve as objective indicators of animal welfare in fisheries (Diggles et al. 2011; Cooke et al. in press b) and can be used to inform conservation actions (Wikelski \& Cooke 2006; Seebacher \& Franklin 2012) given their utility in defining cause and effect relationships and elucidating mechanisms of mortality (Cooke \& O’Connor 2010; Cooke et al. In press a). By determining how species respond to forced submergence associated with incidental capture, we can assist managers in the development of successful and sustainable bycatch reduction strategies. Given that most endangered species legislations extend beyond mortality to include sublethal disturbances (e.g., "harm" and "harassment" are forbidden by the Canadian Species at Risk Act), efforts to document physiological and behavioural impairments could provide an 
objective means of evaluating consequences of different types of fisheries activities while also informing welfare (Diggles et al. 2011). 
Tables

Table 2-1 - Sample sizes, carapace length, and mass of three species of turtles used to assess the sub-lethal consequences of entrapment in commercial fishing nets in Lake Opinicon, Ontario, Canada.

\begin{tabular}{lcccc}
\hline \multicolumn{1}{c}{ Species } & Sex & $\begin{array}{c}\text { Total } N \\
\text { (Control, } \\
\text { Treatment) }\end{array}$ & $\begin{array}{c}\text { Mean carapace } \\
\text { length } \pm \text { SE } \\
\text { (mm) }\end{array}$ & $\begin{array}{c}\text { Mean mass } \pm \\
\text { SE (g) }\end{array}$ \\
\hline $\begin{array}{l}\text { Eastern musk turtle } \\
\text { (Sternotherus odoratus) }\end{array}$ & Male & $18(8,10)$ & $107 \pm 4$ & $186 \pm 16$ \\
$\begin{array}{l}\text { Northern map turtle } \\
\text { (Graptemys geographica) }\end{array}$ & Male & $20(10,10)$ & $115 \pm 6$ & $178 \pm 13$ \\
$\begin{array}{l}\text { Painted turtle } \\
\text { (Chrysemys picta) }\end{array}$ & Male & $16(6,10)$ & $139 \pm 2$ & $330 \pm 12$ \\
\hline
\end{tabular}


Table 2-2 - Description of the six behavioural tests, adapted from LeDain et al. (in press), that were performed on three species of turtles used to assess the sub-lethal consequences of entrapment in commercial fishing nets in Lake Opinicon, Ontario, Canada.

\section{Behavioural Test}

\section{Description}

Escape

Righting (Land)

Righting (Water)

Audible startle

Visual startle

Tactile stimuli
Turtles were held posteriorly and completely submerged for 10 seconds - if any attempt to escape (moving limbs, moving neck/head), the behaviour was present.

Turtles were placed on their carapace, on land, and left for 10 seconds - if successfully able to right or any attempts (limb or head movement) were made, the behaviour was present.

Turtles were placed on their carapace, while being held underwater in a tub - if successfully able to right or any attempts were made (limb or head movement), the behaviour was present.

Turtles were placed in a 14 gallon plastic tub, and were not held. The sides of the tub were gently tapped - if any signs of startle were made (retract head, abrupt change in direction), the behaviour was present.

Turtles were placed in a 14 gallon plastic tub, and were not held. We waved a hand within $10 \mathrm{~cm}$ of their face - if any attempt to retract their head, the behaviour was present.

Turtles were held posteriorly and we gently pinched their tail, a limb and their head - any attempt to retract their limb/head/tail was scored as present. 

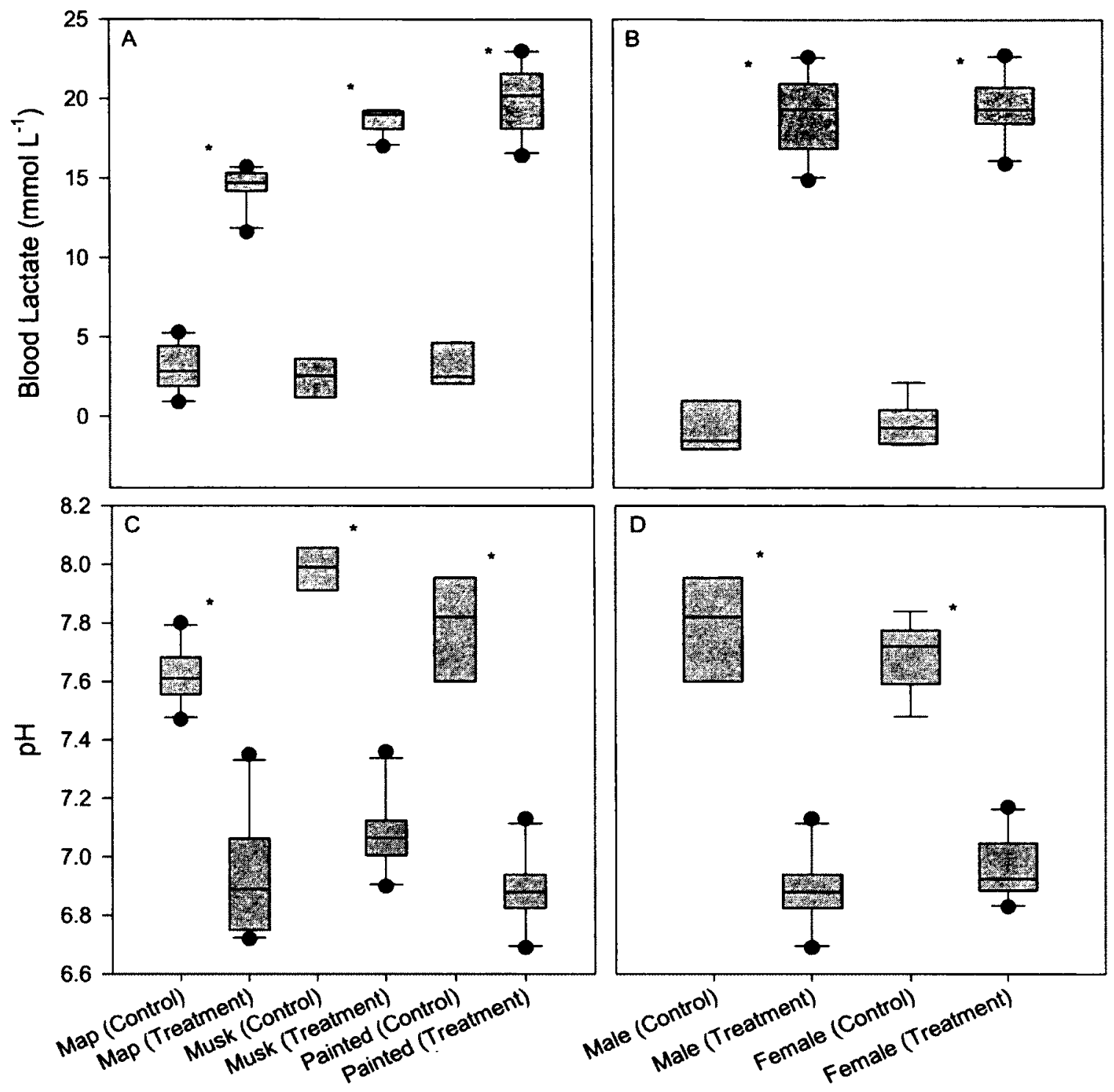

Figure 2-1 - Blood lactate (top) compared between species (A) and sexes (B) and pH (bottom) compared between species (C) and sexes (D) of control and submerged individuals. Median is reported along with the $25^{\text {th }}$ and $75^{\text {th }}$ percentiles. Bars represent the $10^{\text {th }}$ and $90^{\text {th }}$ percentiles and any outliers (black dots) are reported. Significant difference $(p<0.05)$ between control and submerged individuals are represented by asterisks $\left({ }^{*}\right)$. 

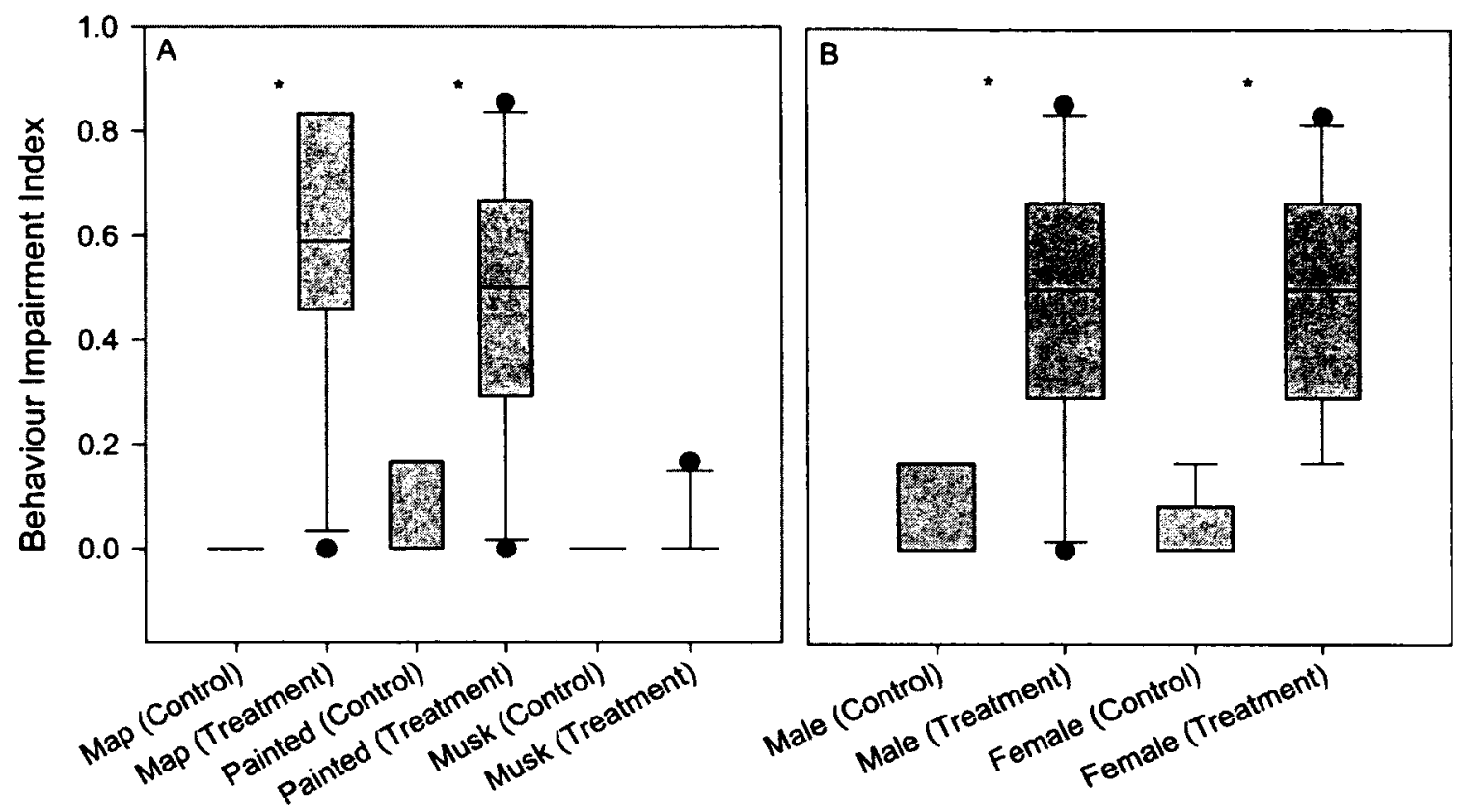

Figure 2-2 - Behaviour Impairment Index (BII) scores after six behavioural tests of control and submerged individuals compared between species (A) and sexes of painted turtles (B). Scores range from 0 , which suggests that the individual was not impaired, to a maximum score of 1 , which indicates that the turtle was completely impaired. Median is reported along with the $25^{\text {th }}$ and $75^{\text {th }}$ percentiles. Bars represent the $10^{\text {th }}$ and $90^{\text {th }}$ percentiles and any outliers (black dots) are reported. Significant difference $(p<0.05)$ between control and submerged individuals are represented by asterisks $\left({ }^{*}\right)$. 


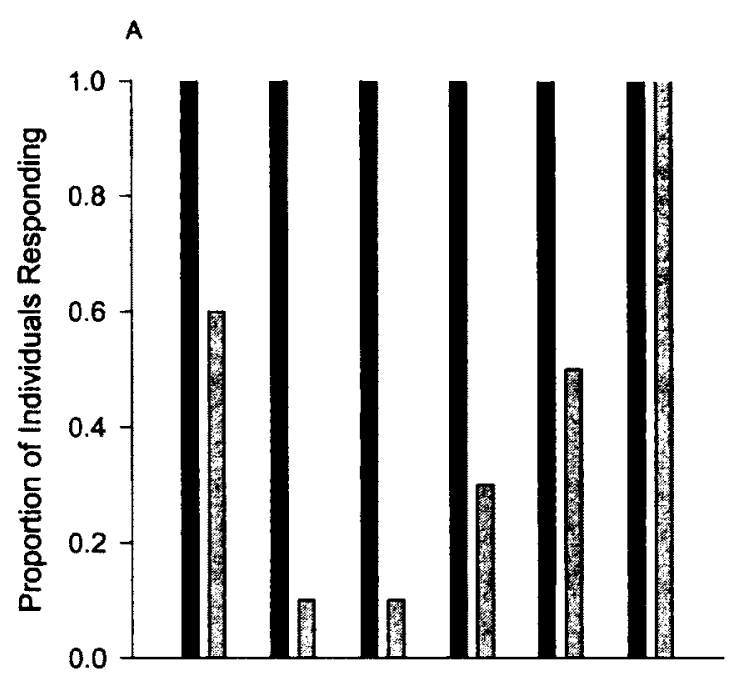

B
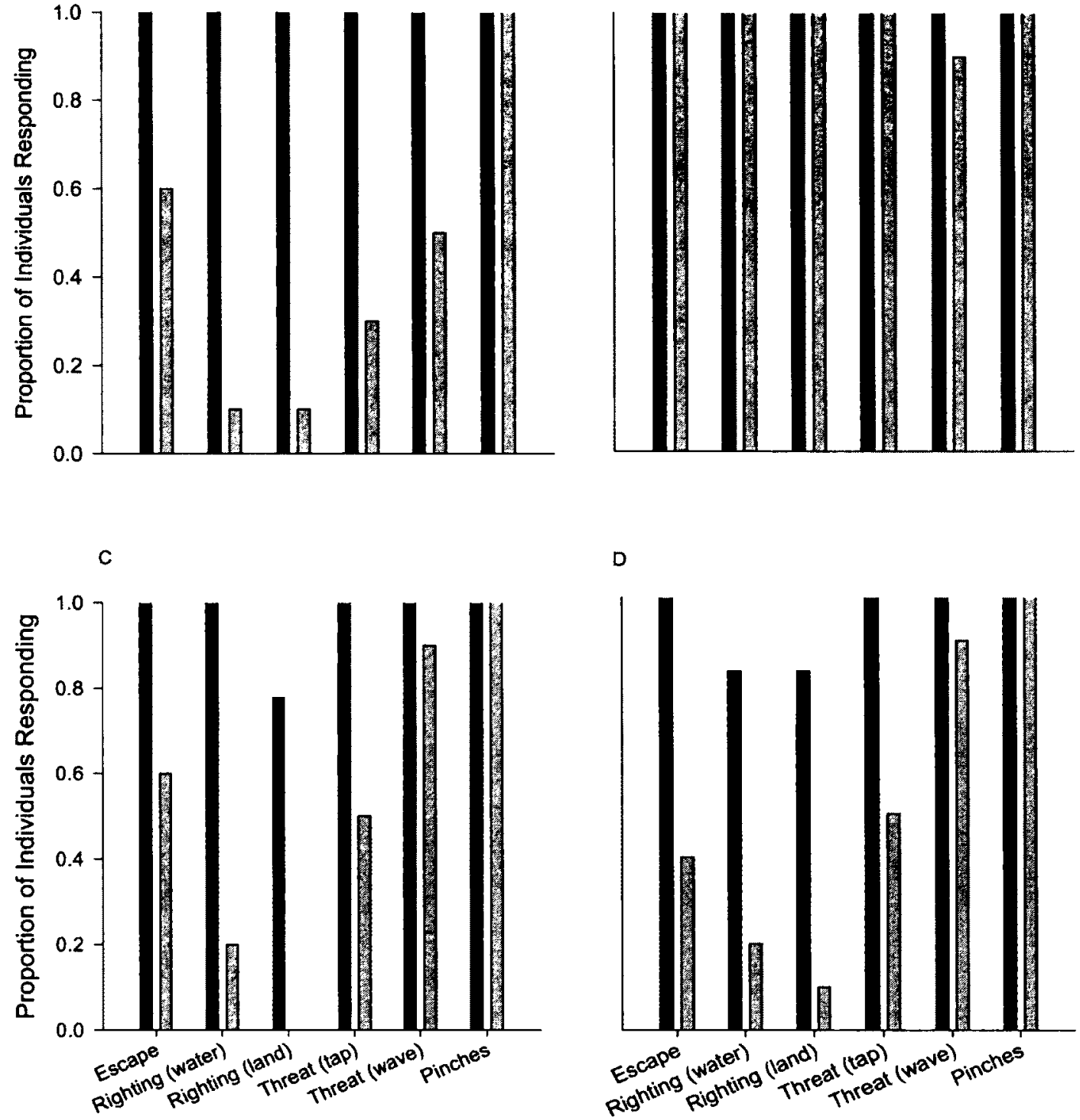

$\mathrm{D}$

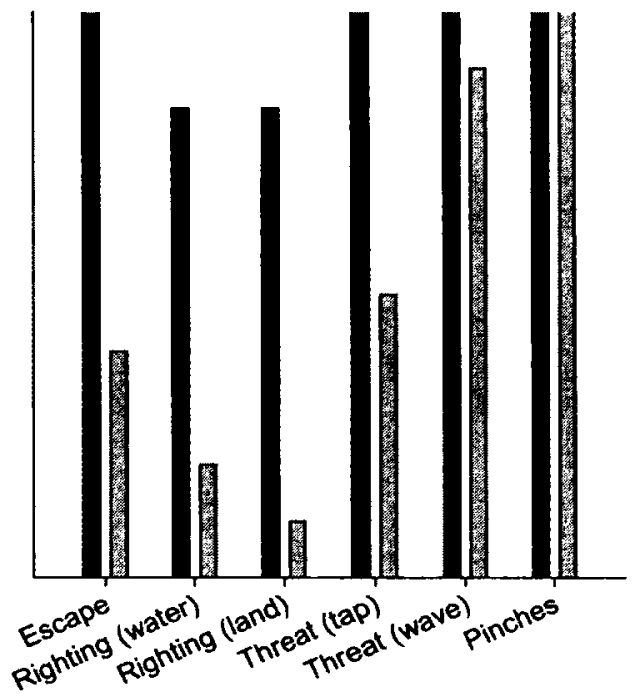

Behavioural Tests

Figure 2-3 - Proportion of individuals that responded with a positive response for each behavioural test for each species; northern map turtle (Graptemys geographica; A), common musk turtle (Sternotherus odoratus; B), female painted turtle (Chrysemys picta; C) and male painted turtle (D). Black bars represent control individuals and submerged individuals in grey. 


\title{
Chapter 3: Biologgers reveal post-release behavioural impairments of freshwater turtles following fisheries interactions
}

\begin{abstract}
Bycatch, the incidental capture of non-target organisms, occurs in both marine and freshwater commercial fisheries. Although immediate bycatch mortality frequently occurs and is a major concern, detrimental sub-lethal effects and potential post-release mortality are also of concern. Turtle populations are especially vulnerable to slight increases in adult mortality from sources such as bycatch. In eastern Ontario, turtles are frequently captured as bycatch in a small-scale freshwater commercial fyke-net fishery and, currently, the fate of discarded turtles is unknown. The purpose of our study was to determine the effect of fyke-net capture on fate and post-release behaviour in two species of freshwater turtles (eastern musk turtle; Sternotherus odoratus, and painted turtle; Chrysemys picta). We used tri-axial accelerometers to study fine-scale movement behaviour of entrapped (exposed to forced submergence for $4 \mathrm{hrs}$ at water temperatures of $23-29^{\circ} \mathrm{C}$ ) and control turtles upon release. We used overall dynamic body acceleration (ODBA) as a measure of movement and assessed differences between control and entrapped turtles over three time intervals up to 48 hours after release. Post-release mortality was not detected in any individuals exposed to simulated capture. Individuals of both species that were exposed to simulated entrapment displayed significantly lower locomotory levels over the first 6 hours. However, that difference disappeared after 48 hours, suggesting the ability to recover, despite decreasing locomotory levels. The use of tri-axial accelerometers in freshwater turtles is novel and allowed us to quantify uninterrupted, fine-scale movement behaviour. Quantifying the post-release and sub-
\end{abstract}


lethal effects of entrapment is important in estimating the population effects associated with bycatch, which is especially important for species at-risk.

\section{Introduction}

Bycatch, the incidental capture of non-target organisms, occurs in most commercial fisheries (Crowder \& Murawski 1998; Hall et al. 2000; Hall \& Mainprize, 2005). Fish bycatch accounted for approximately $28 \%$ of total landings in the United States in 2002 (Harrington et al. 2005). Although mortality frequently occurs, not all individuals caught as bycatch die immediately (Davis 2002). Post-release mortality and detrimental sublethal effects have been reported in a variety of frequently caught bycatch species including marine mammals, sea birds, sharks, and marine turtles (Julian \& Beeson 1998; Lewison et al. 2004; Moore et al. 2008; Finkbeiner et al. 2011). Detrimental sub-lethal effects and post-release mortality can have important negative population consequences that are not always immediately evident and remain largely undocumented (Alverson $e t$ al. 1994; Chopin \& Arimoto 1995; Davis 2002; Lewison et al. 2004). Unknown additional mortality rates are especially concerning for species that have slow maturation and long generation times, and that are at-risk (Crowder et al. 1998; Hall et al. 2000). Injuries and negative physiological effects sustained as a result of bycatch, such as net entanglement (e.g., Frick et al. 2010), hooking injuries (e.g., Aguilar et al. 1995), and stress associated with prolonged submergence in air breathing organisms (e.g., Lutcavage \& Lutz 1991; Harms et al. 2003; Lewison et al. 2005; Snoddy et al. 2009) can be nonlethal, but could still impair behaviour. Behavioural impairments, such as reduced mobility and diminished foraging ability, can increase the risk of mortality (Olla et al. 1997; Schreck et al. 1997; Davis 2002). Furthermore, sub-lethal effects of entrapment 
have the potential to affect the health and fitness of the individual (Davis 2002; Skomal 2007). Various studies have focused on how sub-lethal effects associated with capture manifest themselves behaviourally in several frequently caught species, mostly fish (e.g. sablefish; Davis \& Parker 2011). In addition, studies on fish have indicated that there are interspecific differences in the effects of sub-lethal stressors (Ryer et al. 2004). Identifying how behaviour is impaired following capture, especially fine-scale movement behaviour, is crucial to estimate the overall negative population consequences of bycatch, particularly in at-risk species.

The use of animal-attached sensors or biologgers is becoming increasingly widespread to study fine-scale, continuous animal behaviour and movement in nature (Cooke et al. 2004; Wilson et al. 2008; Cooke 2008; Rutz \& Hays 2009; Bograd et al. 2010). Biologgers encompass a wide range of devices that can measure various parameters, such as temperature, location, acceleration, and pressure (Rutz \& Hays 2009). Biologgers have been used to assess post-release behaviour and associated delayed morality in marine turtles following interaction with fishing gear (e.g., Chaloupka et al. 2004; Swimmer et al. 2006; McClellan \& Read 2009; Snoddy \& Williard 2010). Surprisingly, little information exists on the post-release behaviour of freshwater turtles following interaction with fishing gear, despite freshwater turtles being frequently encountered as bycatch in many inland fisheries (Barko et al. 2004; McClellan et al. 2009; Raby et al. 2011; Larocque et al. 2012a). Unlike marine turtles that are most frequently captured in long line and trawl fisheries, freshwater turtles are mostly encountered in trap net fisheries, such as hoop and fyke-nets (Barko et al. 2004; McClellan et al. 2009; Larocque et al. 2012a). Despite the ability of freshwater turtles to 
withstand extended periods of submergence, prolonged entrapment in fishing nets can result in drowning (Larocque et al. 2012a). In addition, there are acute physiological and behavioural impairments associated with entrapment in fyke-nets in several freshwater turtles (Ledain et al. In press; Stoot et al. In press). Turtles are particularly susceptible to population declines following even slight increases in adult mortality, such as bycatch mortality, because of their naturally high juvenile mortality and delayed sexual maturity (Congdon et al. 1993; 1994; Gibbons et al. 2000).

The purpose of our study was to determine the post-release movement behaviour and fate of freshwater turtles caught as bycatch in commercial fyke-nets. As study species, we chose two representative, but ecologically different, freshwater turtles: the painted turtle (Chrysemys picta) and the musk turtle (Sternotherus odoratus). We exposed individuals of both species to simulated capture stressors and measured their fine-scale movement behaviour with tri-axial accelerometers. Tri-axial accelerometers measure acceleration in three axes $(\mathrm{x}, \mathrm{y}$ and $\mathrm{z})$ to estimate animal orientation and both static and dynamic movements within natural habitats (Yoda et al. 1999; Wilson et al. 2008; Shepard et al. 2008). Both of our study species are frequently caught as bycatch in a small-scale commercial fyke-net fishery on inland lakes and rivers in eastern Ontario (Carrière et al. 2009; McClellan \& Read, 2009; Larocque et al. 2012ab). This small-scale commercial fishery targets sunfish (Lepomis spp.) although bullhead (Ameiurus spp.), yellow perch (Perca flavescens), black crappie (Pomoxis nigromaculatus), and rock bass (Ambloplites rupestris) are also harvested (Burns 2007; Larocque et al. 2012a). Upon landing, all bycatch species are required to be discarded immediately, whether dead or alive. Previous studies have assessed the post-release mortality of commonly encountered fish 
bycatch in this fishery (e.g., northern pike; Colotelo et al. 2013), but the fate of turtles encountered as bycatch is currently unknown.

\section{Materials and Methods}

Study area and turtle collection

We conducted the study on Lake Opinicon ( $\left.44^{\circ} 34^{\prime} \mathrm{N}, 76^{\circ} 19^{\prime} \mathrm{W}\right)$ approximately $100 \mathrm{~km}$ southwest of Ottawa, Ontario, Canada. Experiments were conducted between 14 May and 19 June 2012 when lake water temperatures ranged from 18 to $26^{\circ} \mathrm{C}$. For all experiments, dissolved oxygen was at or near saturation (i.e., $6-8 \mathrm{mg} \cdot \mathrm{l}^{-1}$ ). All turtles were initially collected using fyke-nets, which were set throughout the lake in $2-3 \mathrm{~m}$ of water and left for approximately 24 hours with floats to provide air pockets. We used fyke-nets similar to the ones used in the local commercial fishery. Nets were fished in pairs and were attached by leads (Fig. 1 in Larocque et al. 2012a). Each net contained seven steel hoops, which were $0.5 \mathrm{~m}$ apart and measured $0.9 \mathrm{~m}$ in diameter, and two throats were located in the second and fourth hoop. Two wings and a lead were attached vertically to the mouth of each net. Wings measured $4.6 \mathrm{~m}$ long by $0.9 \mathrm{~m}$ high while each lead measured $10.7 \mathrm{~m}$ long by $0.9 \mathrm{~m}$ high. All gear was fabricated with $2.54 \mathrm{~cm}$ square, 5.08 $\mathrm{cm}$ stretch, nylon mesh. Upon retrieval from the nets, all turtles were returned to the field laboratory where we measured mass and carapace length, and determined the sex based on external characteristics. Individuals were held outdoors in $\sim 700 \mathrm{~L}$ fiberglass tanks at ambient temperatures for approximately 48 hours to let any potential capture stress wane. Tanks were supplied with lake water using a flow though system and turtles were not fed, but were provided with basking platforms and exposed to ambient sunlight. 


\section{Experimental procedure}

We used 32 male turtles of two species for both treatment and control (Table 3-1). We used a treatment group in which turtles were submerged for 4 hours in a closed fykenet set in $1.5 \mathrm{~m}$ of water $\left(23\right.$ to $\left.29^{\circ} \mathrm{C}\right)$, and a control group in which turtles were placed singly into a tank with access to oxygen and a basking platform exposed to ambient sunlight for 4 hours. Four hours of submergence was chosen to provide sufficient time for impairment to occur while avoiding immediate mortality (Larocque et al. 2012b). It should be noted that our submergence length is not representative of typical entrapment length in the Ontario commercial fishery, which can be up to 2-7 days, depending on the season. We used a matched pair design in which, for each individual undergoing the entrapment treatment, we selected a control individual that was matched for species, sex, size, capture day, and capture location. Both individuals from a given pair were released simultaneously at the same location (their capture location).

After initial capture, attachment points were created for the accelerometers by drilling two small holes between the $10^{\text {th }}$ and $12^{\text {th }}$ marginal scutes on the left side. Pairs of control and treatment individuals were then left to recover for a minimum of 48 hours prior to experiments, after which they underwent their respective treatments. After 4 hours in their respective treatments, individuals were removed and tested for basic behavioural responses to assess impairment. Following behavioural assessment, tri-axial accelerometer loggers (model CEFAS G6, $18 \mathrm{~g}$ in air, $10 \mathrm{~Hz}$ recording frequency, $1 \mathrm{~Hz}$ for temperature and depth; CEFAS Technology Limited, Suffolk, United Kingdom) were attached. Tri-axial accelerometers measure both dynamic and static acceleration in units 
of gravity (g). To allow tag retrieval, unique-frequency radio-telemetry transmitters (Model BD-2, $3.2 \mathrm{~g}$ in air, $20 \mathrm{~cm}$ trailing whip antenna, Holohill Systems Inc., Carp, ON, Canada) were also attached to the accelerometers and the entire package weighed approximately $24 \mathrm{~g}$ in air and $\sim 12 \mathrm{~g}$ in water (approximately $5 \%$ of body mass). Tags were attached externally to the posterior left side of the carapace using $13.6 \mathrm{~kg}$ stainless steel trolling line (Figure 1). After logger and transmitter attachment, which lasted 3 minutes on average, both control and treatment turtles were immediately transported to their capture location in large, plastic containers with lids and were released simultaneously. Accelerometers were set to record for $\mathbf{4 8}$ hours and then shut off. Fortyeight hours post-release, turtles were located using a hand-held radio-tracking receiver (Biotracker; Lotek Engineering, Inc.; Newmarket, ON, Canada) and 3-element yagi antenna (AF Antronics, Urbana, IL). Turtles were then recaptured and both tags recovered.

\section{Behavioural assessments}

The use of reflex tests to assess involuntary responses to stimuli, such as touch and gravity have been shown to be useful predictors of mortality in a variety of vertebrates, most notably fish (Davis 2007; 2010). Although not a measure of true reflexes, a variety of behavioural tests have been used to assess impairment related to submergence in freshwater turtles (Ledain et al. In press; Stoot et al. In press). We used six behavioural tests, identical to the ones used in Stoot et al. (In press), which assessed escape ability, righting ability (on both land and water), response to startles (audible/pressure and visual) and tactile stimuli to the head, limbs and tail (See Table 
2.2). If the individual responded to the stimulus, the test was scored as present (1); lack of reaction showed that the response was absent $(0)$. These scores were converted into a Behaviour Impairment Index (BII), which is an overall score of impairment for each individual base on the number of tests performed. The BII ranges from 0 , which indicated that the individual was not impaired, to a maximum score of 1 , which indicates that the turtle was completely impaired and is calculated where BII $=1-$ (sum of individual test scores/total possible score of 6).

Data processing and analysis

Accelerometers were set to record total acceleration (g) at $10 \mathrm{~Hz}$ in three $(\mathrm{x}, \mathrm{y}$ and $\mathrm{z})$ axes. Total acceleration was calculated as the sum of static and dynamic acceleration. Tags were calibrated before deployment by rotating the device through known angles to real g ( $9.8 \mathrm{~m} \mathrm{~s}^{-2}$; Gleiss et al. 2010). Static and dynamic acceleration were separated by weighted smoothing at an interval of $3 \mathrm{sec}$ based on the methods of Shepard et al. (2008) using Igor Pro 6.0 software (WaveMetrics Inc., Lake Oswego, OR). Median ODBA (overall dynamic body acceleration) values were calculated for both species for each time interval of interest.

To ensure that tag burden did not affect experimental groups differently, we ran a one-way t-test to compare the combined mass of tags between control and treatment individuals. To assess the effects of entrapment on movement, we calculated median ODBA values over three time periods post-release for both species: 10 minute intervals for the first hour, 1 hour intervals for the first 6 hours, and 6 hour intervals for the entire 48 hours. Since we sampled the same individuals repeatedly, we used a repeated 
measures two-way ANOVA to test for the effect of time and experimental group on ODBA. We tested for sphericity using Mauchly's test, and if it was violated, we corrected degrees of freedom using Greenhouse-Geisser estimates of sphericity. We conducted follow-up one-way ANOVAs looking at the effect of treatment when there was indication of an interaction or of a main effect. Since our sample size was modest, we conducted follow-up one-way ANOVAs when $p<0.150$. To test for differences in behavioural impairment scores, we used a one-way ANOVA, as residuals did not violate the assumptions or normality and homogeneity of variance, to compare experimental groups within species. All statistical tests were performed using JMP (Version 9.0.1, SAS Institute) and significance was accepted at $\alpha<0.05$.

\section{Results}

Of the 16 pairs of turtles that underwent treatment, all but one painted turtle (from the control treatment) survived for 48 hours. Therefore, we used 7 pairs of painted turtles and 8 pairs of musk turtles to document the effect of entrapment on movement (Table 31). The mass of turtles was similar for control and treatment individuals for both musk $\left(t_{(14)}=0.121, p=0.547\right)$ and painted turtles $\left(t_{(12)}=0.326, p=0.625\right)$, which indicates that tag burden was equal in both groups for both species.

We examined ODBA as a proxy for locomotory activity every 10 minutes for the first hour post-release and found no significant interaction between time and treatment in painted turtles $\left(F_{(1.99,23.93)}=0.668, p=0.522\right)$ or in musk turtles $\left(F_{(5,10)}=1.986, p=\right.$ 0.167). There was no significant difference in movement over time in painted turtles $\left(F_{(1.99,23.93)}=2.426, p=0.110\right)$ or in musk turtles $\left(F_{(5,10)}=1.283, p=0.344\right)$, although there was some evidence that painted turtles experienced some decrease in movement 
over time (Fig. 3-2A \& 3-2B). In addition, we did not find significance differences in ODBA between experimental groups in painted turtles $\left(F_{(1,12)}=3.454, p=0.088\right)$ or in musk turtles $\left(F_{(1,14)}=2.837, p=0.114\right)$, although the difference approached statistical significance in both cases. Therefore, we conducted follow-up one-way ANOVAs that revealed that experimental groups had significantly lower ODBA in musk turtles during $0-10,10-20$ and 30-40 minutes after release, as well as during 40-50 minutes after release in painted turtles. This suggests that submerged individuals had impaired movements during these time intervals (Table 3-2).

We examined ODBA as a proxy for locomotory activity each hour for the first 6 hours post-release and found no significant interaction between time and treatment in painted turtles $\left(F_{(2.25,26.94)}=1.142, p=0.339\right)$ or in musk turtles $\left(F_{(2.32,32.48}=0.515, p=\right.$ 0.629). There was a significant difference in movement over time in painted turtles $\left(F_{(2.25,26.94)}=4.325, p=0.020\right)$ that tended to have decreased movement over time, but not in musk turtles $\left(F_{(2.32,32.48)}=2.576, p=0.084\right)$ although again the difference approached significance with musk turtles tending to show decreased movement over time (Fig. 3-2C \& 3-2D). We did find significant differences in ODBA between experimental groups in painted turtles $\left(F_{(1,12)}=5.912, p=0.032\right)$ and in musk turtles $\left(F_{(1,14)}=4.588, p=0.050\right)$ where entrapped individuals had lower levels of locomotory activity compared to controls.

We examined ODBA as a proxy for locomotory activity every 6 hours for 48 hours post-release and found no significant interaction between time and treatment in painted turtles $\left(F_{(2.61,31.33)}=0.102, p=0.943\right)$ or in musk turtles $\left(F_{(7,8)}=0.427, p=0.861\right)$. There was no difference over time in painted turtles $\left(F_{(2.61,31.33)}=2.859, p=0.059\right)$ or in 
musk turtles $\left(F_{(7,8)}=2.273, p=0.136\right)$, but again the differences approached significance with both species tending to move more with time (Fig. 3-2E \& 3-2F). We found no significant difference in ODBA between experimental groups in painted turtles $\left(F_{(1,12)}=\right.$ $0.097, p=0.761)$ or in musk turtles $\left(F_{(1,14)}=2.823, p=0.115\right)$ over this longer time interval.

We also investigated the immediate impairment associated with entrapment by using a behavioural impairment index (BII). There was a significant difference in BII scores between control and submerged groups for painted turtles (partial $\mathrm{R}^{2}=0.56, F_{(1,12)}=$ $15.38, p=0.002)$. Experimentally submerged painted turtles had significantly lower BII scores, which suggests impairment after 4 hours of simulated fyke-net entrapment. No significant difference was found between control and submerged musk turtles (partial $\mathrm{R}^{2}$ $=0.13, F_{(1,14)}=2.00, p=0.179$; Fig. $\left.3-3 \& 3-4\right)$, suggesting that submerged musk turtles were not behaviourally impaired.

\section{Discussion}

Our main objective was to determine the post-release consequences of fyke-net entrapment on two species of freshwater turtles commonly encountered as bycatch. We only found delayed mortality in one individual, a control painted turtle. Mortality occurred shortly after release and the cause of mortality is unknown as the individual was not exposed to the submerged treatment and had access to oxygen throughout its trial. Although there are previous reports of external electronic tags of painted turtles becoming fouled by algae or macrophytes (Boarman et al. 1998), there was no fouling of the biologger on the dead turtle upon retrieval. We used tri-axial accelerometers to measure fine scale movement, which enabled us to investigate potential impairment over 
three time periods post-release: initial (1 hour post-release at 10 minute intervals), shortterm ( 6 hours post-release at 1 hour time intervals), and medium-term ( 48 hours postrelease at 6 hour time intervals). We did find evidence suggesting that individuals from both species exposed to simulated net entrapment had impaired locomotory activity relative to control animals, at least in the first 6 hours after release. Studies looking at post-release mortality rates in marine turtles are relatively common (Chaloupka et al. 2004; Swimmer et al. 2006; Snoddy \& Willard 2010). To our knowledge, however, there are no previous studies looking at post-release mortality and locomotory impairments associated with entrapment in freshwater turtles, despite its importance in understanding the fate of turtles encountered as bycatch.

Previous studies have assessed the physiological response to fyke-net entrapment in painted and musk turtles and revealed that both species experience significant physiological impairment after 3 hours of simulated entrapment (Stoot et al. In press). Furthermore, despite similar physiological impairment, not all species were behaviourally impaired following entrapment; musk turtles did not have significant behavioural impairment whereas painted turtles were significantly impaired (Stoot et al. In press), as was the case in the present study. Although painted turtles are tolerant of true anoxic conditions in cold water, submergence in elevated normoxic conditions makes them incapable of sequestering sufficient oxygen through secondary gas exchange mechanisms to remain aerobic (Ultsch \& Jackson 1982; Jackson et al. 2000; Reese et al. 2001), thus requiring them to metabolize energy anaerobically, which leads to blood acidosis (Ultsch \& Jackson 1982; Ultsch et al. 1999; Jackson et al. 2000; Reese et al. 2001). Unlike painted turtles, musk turtles are intolerant of submergence in anoxic conditions, but use 
an alternative strategy to tolerate submergence in normoxic conditions called bimodal respiration, which is the gas exchange via extrapulmonary oxygen uptake (Ultsch et al. 1984; Reese et al. 2001).

Overall, our research suggests that the movements of both painted and musk turtles are impaired (i.e., decreased locomotory activity levels) to some extent within the first 6 hours after release from simulated incidental capture. Therefore, simulated entrapment in fyke-nets for 4 hours can cause impairments, which affect locomotory ability. This suggests that turtles released alive from commercial fishing nets may have reduced abilities to flee when faced with predators, or rapidly approaching boats (Galois \& Ouellet, 2007; Bulté et al. 2010).

Painted turtles had higher overall median ODBA values through all three time periods compared to musk turtles, which is most likely a result of their superior locomotory ability. Painted turtles are known to be free-swimming while musk turtles tend to be more bottom crawlers (Ernst et al. 1994). Tag weight could also have contributed to interspecific differences in locomotion because painted turtles are heavier than musk turtles and, therefore, the tags represented a smaller burden proportionally. Nonetheless, the tag mass in water was $\sim 12 \mathrm{~g}$ which constitutes, on average, only $\sim 4 \%$ of the mass of painted turtles and $\sim 6 \%$ of the mass of musk turtles used in this study. General rules for vertebrates suggest tag mass should not exceed 3\% of body mass (Putman 1995). Tags were positioned well back on the carapace, consistent with best practices for turtle tagging (Boarman et al. 1998; Balazs 1999). 
Behavioural tests indicated that the two species respond differently to simulated capture. These behavioural tests have previously been used in freshwater turtles to assess behavioural impairment associated with entrapment (Ledain et al. In press; Stoot et al. In press). As indicated, BII scores of submerged individuals were significantly lower than those of control in painted turtles, but musk turtles did not have significantly different BII scores between experimental groups suggesting that they were not impaired. Musk turtles had similar proportions of submerged individuals responding to each test as the control individuals. From these results, we would not have expected to detect impaired locomotory behaviour in musk turtles, which highlights the usefulness of measuring finescale movement behaviour to detect subtle impairments.

We also wanted to quantify the duration of potential impairment in both musk and painted turtles. Despite seeing impairment effects over 6 hours after release, we did not find significant locomotory differences between control and submerged groups over 48 hours after release. In addition, activity levels seem to stabilize and converge over time between experimental groups in both species. This suggests that individuals have recovered and are no longer experiencing locomotory impairment past 6 hours. Within the eastern Ontario fyke-net fishery, turtles can typically remain entrapped in nets for up to 48 hours at elevated water temperatures (similar to this study) and up to 7 days at cooler temperatures $\left(-10-12^{\circ} \mathrm{C}\right)$. We would expect to see more obvious locomotory impairments in both species when exposing individuals to longer submergence periods. In fact, these prolonged submergence times result in high mortality rates (Larocque et al. 2012a). 
Our study shows the importance of evaluating post-release fate on various time scales. Assessing fine-scale locomotory activity over the short-term revealed impairment patterns that were not present over the longer-term. Impaired locomotion can increase the risk of mortality and predation (Davis 2002). In addition, it is important to identify postrelease effects as harm and harassment of species at-risk violates the Species at Risk Act in Canada (2002, c.29, s.32). By identifying species-specific responses to entrapment, we can determine how species respond to incidental capture and use this information to inform management. Electronic tagging techniques such as those used here hold much promise for the study of post-release bycatch behaviour and fate (Cooke 2008; Donaldson et al. 2008). The obvious next step is to quantify in more detail the increased risk of mortality that results from locomotory impairments within the first 6 hours following release from nets in freshwater turtles. 


\section{Tables}

Table 3-1 - Sample sizes, mean pair carapace length, and mean pair mass of two species of turtles used to assess the post-release of entrapment in commercial fishing nets in Lake Opinicon, Ontario, Canada.

\begin{tabular}{lcccc}
\hline \multicolumn{1}{c}{ Species } & Sex & $\begin{array}{c}\text { Number of } \\
\text { pairs }\end{array}$ & $\begin{array}{c}\text { Mean pair } \\
\text { carapace length } \\
\pm \text { SE (mm) }\end{array}$ & $\begin{array}{c}\text { Mean pair } \\
\text { mass } \pm \text { SE (g) }\end{array}$ \\
\hline $\begin{array}{l}\text { Eastern musk turtle } \\
\text { (Sternotherus odoratus) }\end{array}$ & Male & 8 & $116 \pm 1$ & $218 \pm 4$ \\
$\begin{array}{l}\text { Painted turtle } \\
\text { (Chrysemys picta) }\end{array}$ & Male & 7 & $137 \pm 3$ & $309 \pm 17$
\end{tabular}


Table 3-2 - Follow-up one-way ANOVA results between experimental groups looking at 10 minute intervals over the initial first hour after release. Significant results are denoted with an asterisk $(*)$.

\begin{tabular}{cccccc}
\hline Species & Time period (minutes) & Partial R $^{2}$ & $\boldsymbol{F}$ ratio & $\begin{array}{c}\text { Degrees of } \\
\text { freedom }\end{array}$ & $\boldsymbol{p}$-value \\
\hline Musk & $0-10$ & 0.277 & 5.370 & 1,14 & $\mathbf{0 . 0 3 6}^{*}$ \\
Musk & $10-20$ & 0.299 & 5.978 & 1,14 & $\mathbf{0 . 0 2 8}^{*}$ \\
Musk & $20-30$ & 0.002 & 0.278 & 1,14 & 0.607 \\
Musk & $30-40$ & 0.292 & 5.789 & 1,14 & $\mathbf{0 . 0 3 1 ^ { * }}$ \\
Musk & $40-50$ & 0.023 & 0.327 & 1,14 & 0.577 \\
Musk & $50-60$ & 0.089 & 1.366 & 1,14 & 0.262 \\
Painted & $0-10$ & 0.034 & 0.425 & 1,12 & 0.527 \\
Painted & $10-20$ & 0.000 & 0.010 & 1,12 & 0.922 \\
Painted & $20-30$ & 0.208 & 3.154 & 1,12 & 0.101 \\
Painted & $30-40$ & 0.164 & 2.348 & 1,12 & 0.151 \\
Painted & $40-50$ & 0.324 & 5.765 & 1,12 & $\mathbf{0 . 0 3 4 *}$ \\
Painted & $50-60$ & 0.198 & 2.961 & 1,12 & 0.111
\end{tabular}


Table 3-3 - Follow-up one-way ANOVA results between experimental groups looking at 1 hour intervals over the initial 6 hours after release. Significant results are denoted with an asterisk $\left({ }^{*}\right)$.

\begin{tabular}{cccccc}
\hline Species & Time period (hrs) & Partial R $^{2}$ & $\boldsymbol{F}$ ratio & Degrees of freedom & $\boldsymbol{p}$-value \\
\hline Musk & $0-1$ & 0.143 & 2.34 & 1,14 & 0.148 \\
Musk & $1-2$ & 0.132 & 2.126 & 1,14 & 0.167 \\
Musk & $2-3$ & 0.218 & 3.895 & 1,14 & 0.069 \\
Musk & $3-4$ & 0.094 & 1.458 & 1,14 & 0.247 \\
Musk & $4-5$ & 0.084 & 1.286 & 1,14 & 0.276 \\
Musk & $5-6$ & 0.180 & 3.082 & 1,14 & 0.101 \\
Painted & $0-1$ & 0.019 & 2.882 & 1,12 & 0.115 \\
Painted & $1-2$ & 0.025 & 0.303 & 1,12 & 0.592 \\
Painted & $2-3$ & 0.004 & 0.049 & 1,12 & 0.829 \\
Painted & $3-4$ & 0.063 & 0.806 & 1,12 & 0.3871 \\
Painted & $4-5$ & 0.140 & 1.947 & 1,12 & 0.1882 \\
Painted & $5-6$ & 0.026 & 0.319 & 1,12 & 0.5833
\end{tabular}


Table 3-4 - Follow-up one-way ANOVA results between experimental groups looking at 6 hour intervals over 48 hours after release. Significant results are denoted with an asterisk $(*)$.

\begin{tabular}{cccccc}
\hline Species & Time period (hrs) & $\begin{array}{c}\text { Partial } \\
\mathbf{R}^{\mathbf{2}}\end{array}$ & $\boldsymbol{F}$-ratio & $\begin{array}{c}\text { Degrees of } \\
\text { freedom }\end{array}$ & $\boldsymbol{p}$-value \\
\hline Musk & $0-6$ & 2.133 & 3.796 & 1,14 & 0.072 \\
Musk & $6-12$ & 0.177 & 3.016 & 1,14 & 0.105 \\
Musk & $12-18$ & 0.069 & 1.038 & 1,14 & 0.326 \\
Musk & $18-24$ & 0.958 & 1.484 & 1,14 & 0.243 \\
Musk & $24-30$ & 0.041 & 0.605 & 1,14 & 0.450 \\
Musk & $30-36$ & 0.000 & 0.005 & 1,14 & 0.944 \\
Musk & $36-42$ & 0.076 & 1.156 & 1,14 & 0.301 \\
Musk & $42-48$ & 0.037 & 0.531 & 1,14 & 0.478 \\
Painted & $0-6$ & 0.113 & 1.523 & 1,12 & 0.241 \\
Painted & $6-12$ & 0.035 & 0.436 & 1,12 & 0.522 \\
Painted & $12-18$ & -7.000 & 0.000 & 1,12 & 1.000 \\
Painted & $18-24$ & 0.152 & 2.148 & 1,12 & 0.169 \\
Painted & $24-30$ & 0.003 & 0.040 & 1,12 & 0.846 \\
Painted & $30-36$ & 0.003 & 0.319 & 1,12 & 0.583 \\
Painted & $36-42$ & 0.001 & 0.013 & 1,12 & 0.910 \\
Painted & $42-48$ & 0.008 & 0.095 & 1,12 & 0.763
\end{tabular}


Figures

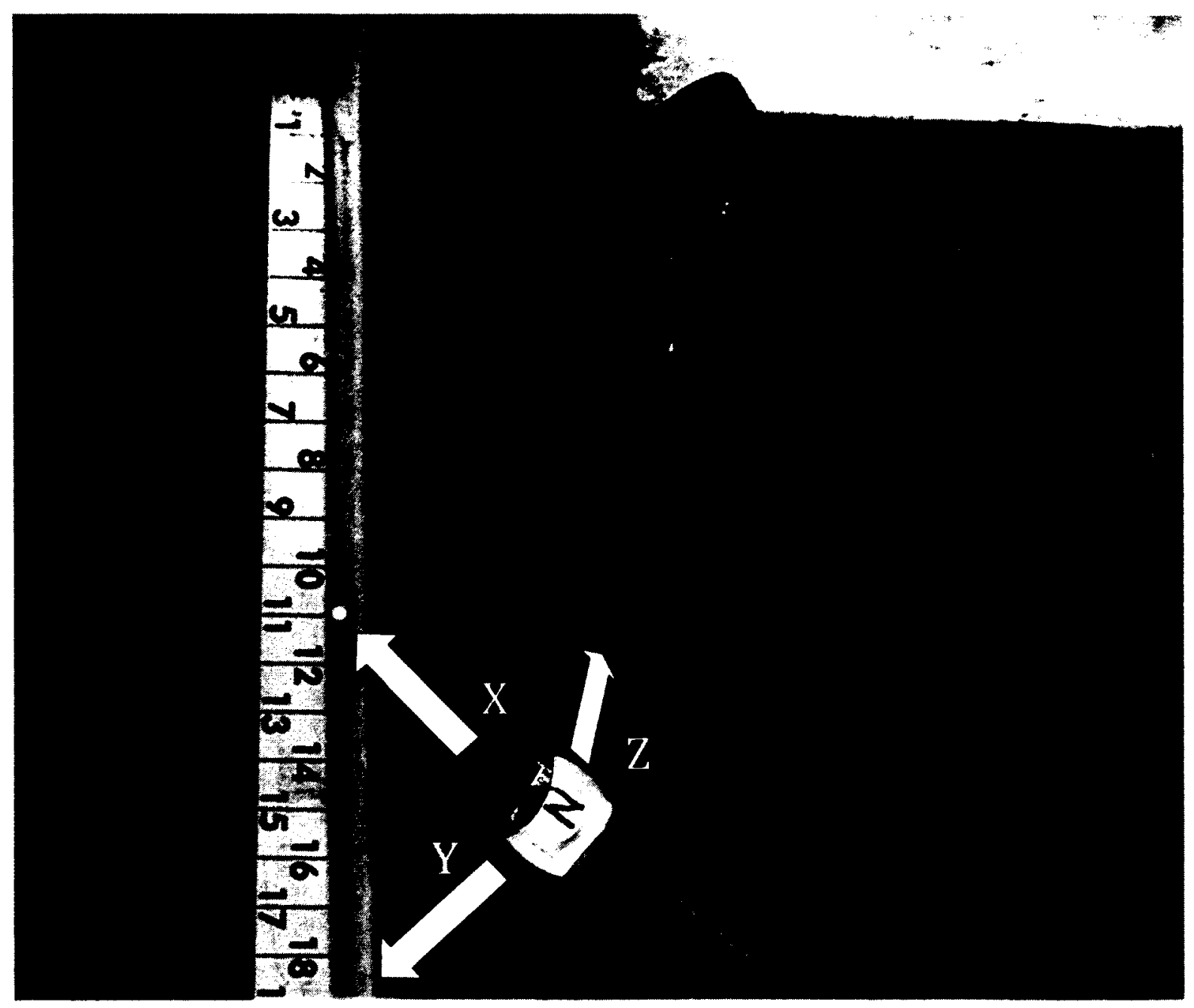

Figure 3-1 - Placement of accelerometer device on left side of a tagged painted along with a radio transmitter. Arrows show direction of $x, y$ and $z$-axis. 


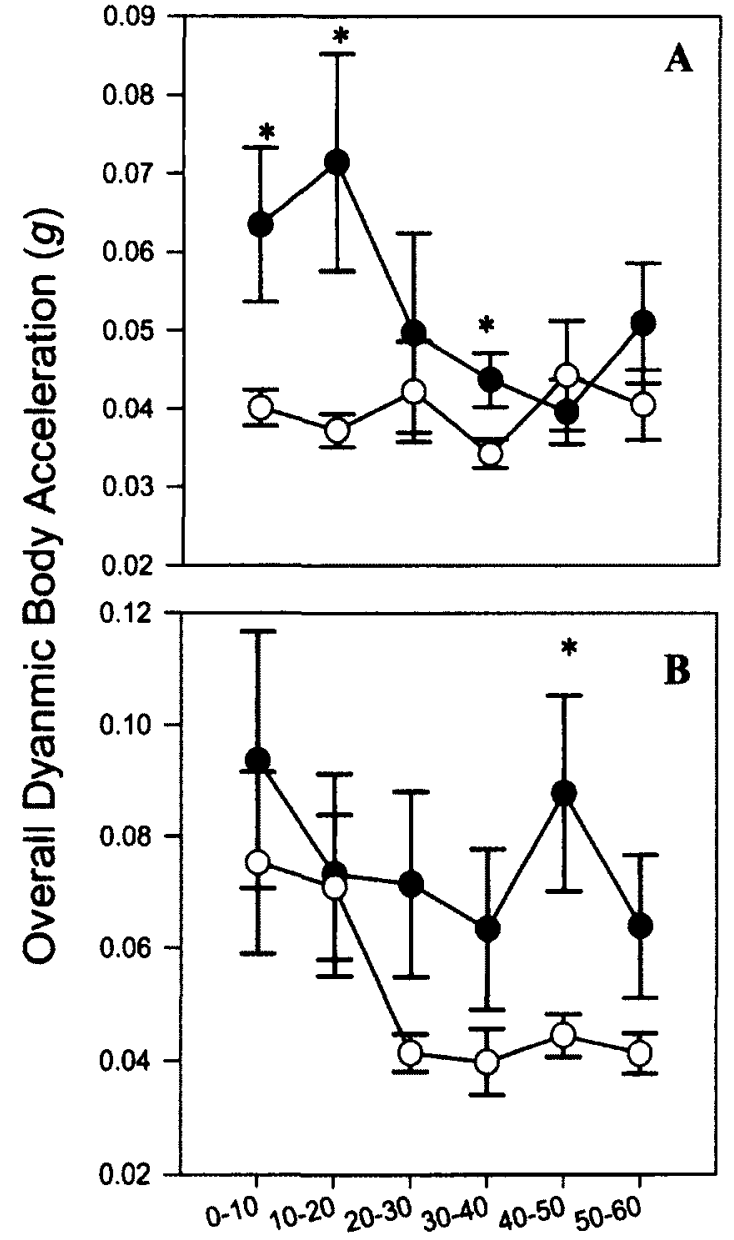

Time after release (minutes)
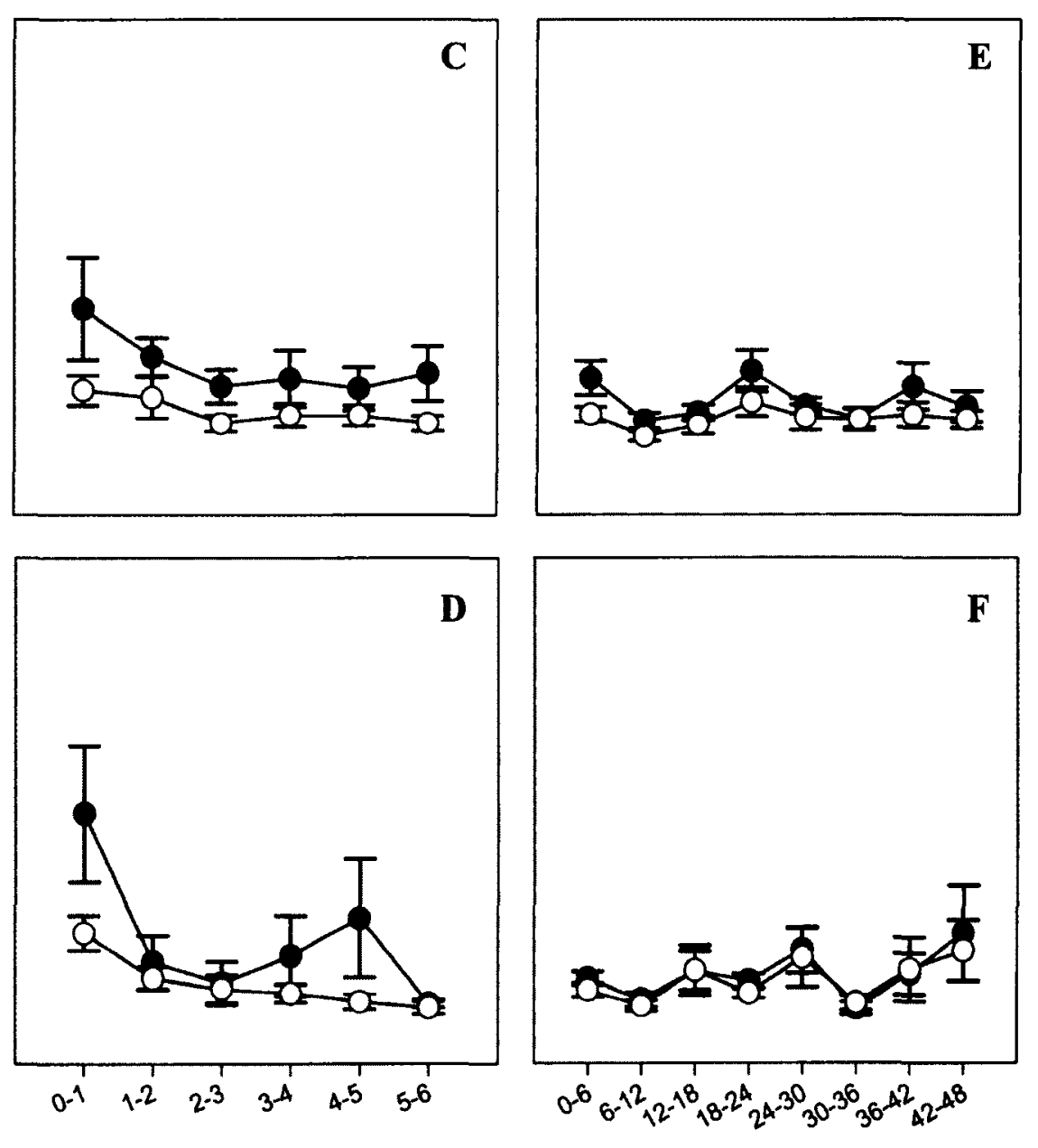

Time after release (hrs)

Figure 3-2 -Least squares means of ODBA (y-axis in $g$ ) over three time periods looking at eastern musk turtles (Sternotherus odoratus; top) and painted turtles (Chrysemys picta; bottom) over three time periods; 1st hour post-release (A \& B), 6 hours post-release (C \& D) and 48 hours post-release (E \& F). Control individuals (black circles) are compared to submerged individuals (white circles) with error bars representing standard error. Significant follow-up one-way ANOVAs are denoted with an asterisk $\left({ }^{*}\right)$. Note: $y$-axis differs between species. 


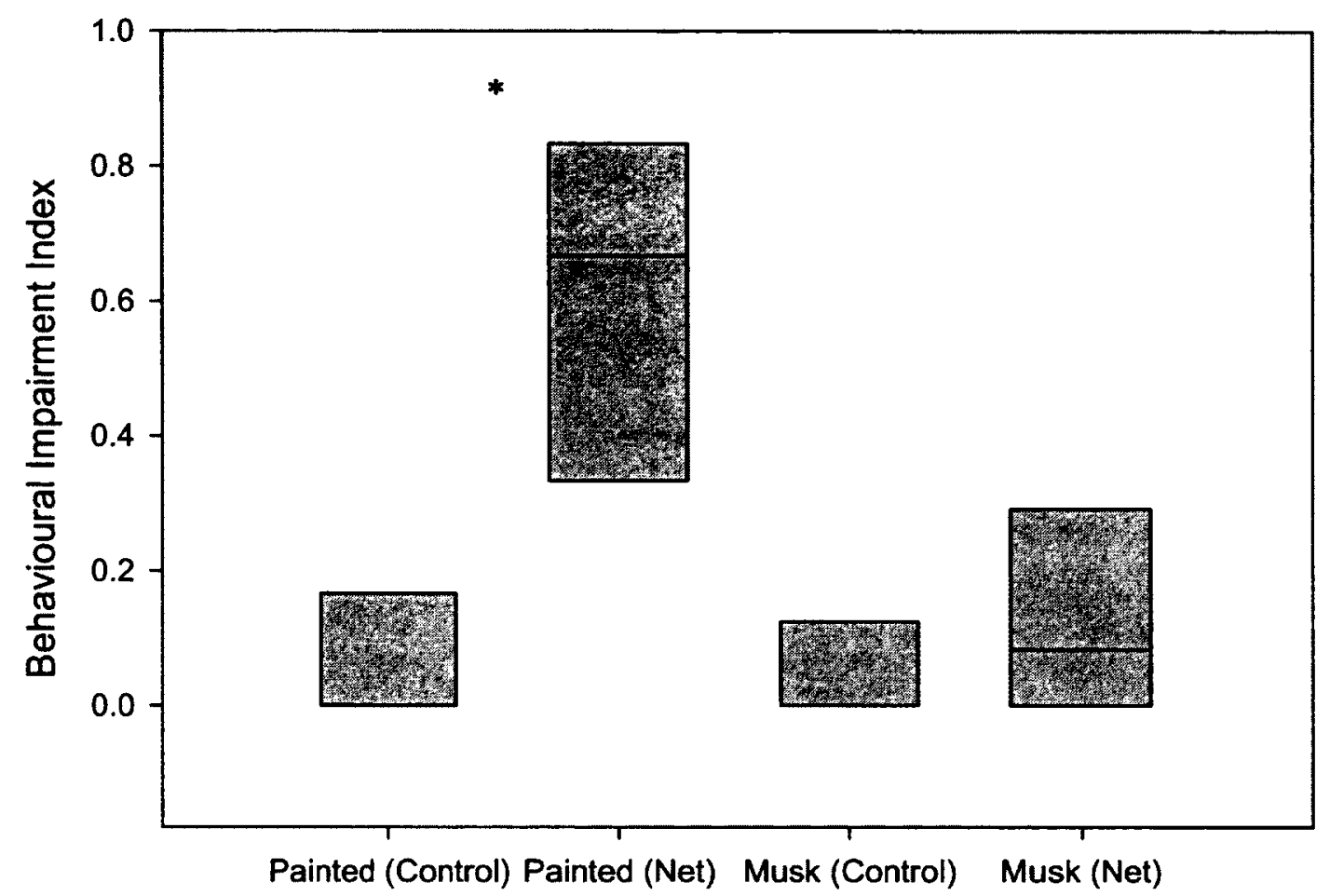

Figure 3-3 - Behaviour Impairment Index (BII) scores after six behavioural tests of control and net submerged individuals compared between species. Scores range from 0 , which suggests that the individual was not impaired, to a maximum score of 1 , which indicates that the turtle was completely impaired. Median is reported along with the $25^{\text {th }}$ and $75^{\text {th }}$ percentiles. Significant difference $(p<0.05)$ between control and submerged individuals are represented by asterisks $\left({ }^{*}\right)$. 

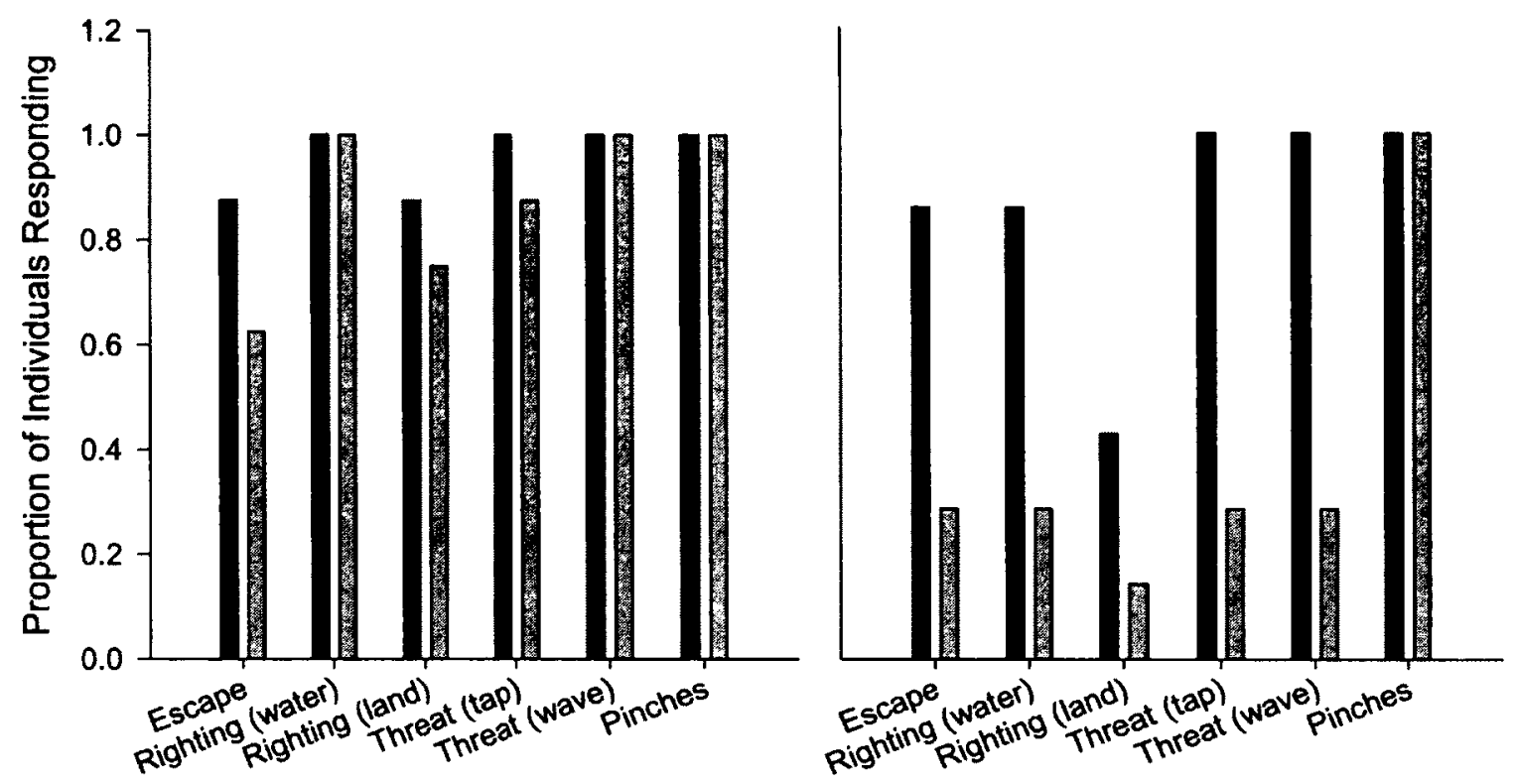

Behavioural Tests

Figure 3-4 - Proportion of individuals that responded with a positive response for each behavioural test for each species; eastern musk turtles (Sternotherus odoratus; left) and painted turtle (Chrysemys picta; right). Black bars represent control individuals and submerged individuals in grey. 


\section{Chapter 4: General Discussion}

The purpose of this thesis was to assess sub-lethal consequences associated with freshwater turtle bycatch in a small-scale commercial fishery. Immediate effects were investigated in Chapter 2 by assessing impairment related to entrapment using physiological parameters, such as blood lactate and $\mathrm{pH}$ as well as behavioural and reflex indicators. This investigation revealed the presence of species-specific responses to submergence and the potential for incongruence between physiological and behavioural responses. In Chapter 3, I evaluated the post-release locomotory consequences and potential delayed mortality related to entrapment.

\section{Findings and Implications}

To date, very few studies have investigated freshwater turtle bycatch (e.g., Barko et al. 2004; Lowry et al. 2005; Fratto et al. 2008; Larocque et al. 2012abc). Although immediate mortality is a clear concern, the presence of sublethal effects and associated post-release mortality remain largely undocumented and unknown (Davis 2002). Sublethal effects and associated mortality can have important population consequences, especially in long-lived, slow-growing species such as turtles (Congdon et al. 1993; 1994). I revealed that entrapment of three species of freshwater turtles (map, painted and musk) caused physiological impairments compared to control groups. Behaviour was also impaired following submergence in both painted and map turtles, although musk turtles were not impaired after exposure to simulated entrapment conditions. These results suggest that despite the presence of physiological impairment following entrapment, these effects are not always manifested behaviourally, suggesting a disconnect between 
physiology and behaviour. Furthermore, I did not see any differences between males and females when exposed to simulated entrapment, which implies that both sexes respond similarly. I have also demonstrated the limitations of using surrogate species in a diverse turtle community.

In Chapter 3, I used fine-scale tri-axial accelerometers to assess the presence of locomotory impairment post-release in freshwater turtles exposed to simulated entrapment conditions. Until now, the post-release effects and associated fate of released freshwater turtles were unknown. I used overall dynamic body acceleration (ODBA) as an estimate of locomotory activity over three time periods: initial ( 1 hour post-release at 10 minute intervals), short-term ( 6 hours post-release at 1 hour time intervals) and medium-term ( 48 hours post-release at 6 hour time intervals) using painted turtles (Chrysemys picta) and eastern musk turtles (Sternotherus odoratus). Although I did not find post-release mortality in any individual exposed to simulated capture, submergence time ( 4 hours) was very conservative as entrapment times at similar temperatures can range up to 48 hours and or even longer (e.g., up to 7 days in Ontario) at cooler temperatures during real fishing. Furthermore, individuals of both species that were exposed to simulated entrapment displayed lower levels of locomotory activity over the first 6 hours following release. However, that difference disappeared after 48 hours, suggesting the ability to recover.

In conclusion, my results from Chapters 2 and 3 suggest that turtles encountered as bycatch display sub-lethal effects immediately after capture and several hours postrelease. Managers will need to acknowledge and incorporate the presence of these sub- 
lethal effects into management plans. Capture in fyke-nets results in harm and harassment of these at-risk freshwater turtles, which is in direct violation of the Canadian Species at-Risk Act (2002, c.29, s.32). Furthermore, documenting the presence of species-specific responses and tolerance is useful when strategizing the use of various bycatch reduction programs (Hall et al. 2000). Knowing how species respond to submergence and associated tolerances can be useful when implementing bycatch reduction devices, as $100 \%$ exclusion rate is rarely possible. This thesis will give managers better information on how the sub-lethal effects associated with incidental capture are affecting freshwater turtles both immediately and post-release.

\section{Future Directions}

This thesis contributed important information towards quantifying the sub-lethal effects associated with freshwater turtle bycatch. This is the first step towards identifying the individual consequences associated with entrapment, excluding individuals that succumb. Further steps would be to evaluate the sub-lethal effects on all turtle species encountered in this fishery. Although I was able to study the presence of post-release mortality in musk and painted turtles, map turtles are particularly poor at tolerating submergence (Reese et al. 2001). In addition, further research should investigate the effect of longer entrapment periods, more typical of the actual fishery. My entrapment durations ( 3 to 4 hours) were conservative as I wanted to expose animals to reasonable stressors without causing mortality. Conducting these studies earlier in the season at cooler temperatures would allow longer, more realistic submergence periods to be used. 
In terms of assessing long-term effects associated with entrapment, important next steps should evaluate how sub-lethal effects associated with entrapment influence the fitness of individuals. Furthermore, using this information, we could determine how sublethal effects influence populations and if these effects can result in population declines. Using this information to assess the conservation status of these populations and the effects of incidental capture on freshwater turtles can help managers make the necessary decisions and changes. 


\section{Literature Cited}

Aguilar R, Mas J, Pastor X (1995) Impact of Spanish swordfish longline fisheries on the loggerhead sea turtle Caretta caretta population in the western Mediterranean. In: Richardson J, Richarson TH (eds) Proceedings of the 12ths annual symposium on sea turtle biology and conservation. NOAA Tech Mem NMFS-SEFSC-361 p 1-6

Alfaro-Shigueto J, Mangel JC, Bernedo F, Dutton PH, Seminoff JA, Godley BJ (2011) Small-scale fisheries of Peru: a major sink for marine turtles in the Pacific. J Appl Ecol 48:1432-1440

Allen JD, Abell R, Hogan Z, Revenga C, Taylor BW, Welcomme RL, Winemiller K (2005) Overfishing of Inland Waters. Bioscience 55:1041-1051

Alverson DL, Freeberg MH, Murawaski SA, Pope JG. (1994) A global assessment of fisheries bycatch and discards. FAO Fisheries technical paper no. 339. Rome, FAO

Anderson NL, Wack RF, Hatcher R (1997) Hematology and clinical chemistry reference ranges for clinically normal, captive New Guinea snapping turtle (Elseya novaeguineae) and the effects of temperature, sex, and sample type. J Zoo Wildlife Med 28:394-403

Balazs GH (1999) Factors to consider in the tagging of sea turtles In: Eckert KL, Bjorndal KA, Abreu-Grobois FA, Donnelly M (eds). Research and Management Techniques for the Conservation of Sea Turtles. IUCN/SSC Marine Turtle Specialist Group Publication No. 4. 
Barko VA, Briggler JT, Osendorf DE (2004) Passive fishing techniques: a cause of turtle mortality in the Mississippi River. J Wildlife Manage 68:1145-1150

Belkin DA (1963) Anoxia: tolerance in reptiles. Science 139:492-493

Bennett AF (1978) Activity metabolism of the lower vertebrates. Ann Rev Physiol $40: 447-469$

Boarman WI, Beigel ML, Goodlett GC, Sazaki M (1998) Passive integrated transponder system for tracking animal movements. Wild Soc Bull 26:886-891

Bograd SJ, Block BA, Costa DP, Godley BJ (2010) Biologging technologies: new tools for conservation. Introduction. Endang Species Res 10:1-7

Bolten AB, Bjorndal KA (1992) Blood profiles for a wild population of green turtles (Chelonia mydas) in the southern Bahamas: size-specific and sex-specific relationships. J Wildlife Dis 28:407-413

Brenner D, Lewbart G, Stebbins M, Herman DW (2002) Health survey of wild and captive bog turtles (Clemmys muhlenbergii) in North Carolina and Virginia. J Zoo Wildlife Med 33:311-316

Brown JA, Watson J, Bourhill A, Wall T (2008) Evaluation and use of the Lactate Pro, a portable lactate meter, in monitoring the physiological well-being of farmed Atlantic cod (Gadus morhua). Aquaculture 285:135-140 
Bulté G, Carrière M-A, Blouin-Demers G (2010) Impact of recreational boating on two populations of northern map turtles (Graptemys geographica). Aquatic Conserv: Mar Freshw Ecosyst 20:31-38

Burke VJ, Lovich JE, Gibbons JW (2000) Conservation of freshwater turtles. In: Klemens MW (ed) Turtle Conservation. Smithsonian Institution Press, Washington, DC, p 156-179

Burns C (2007) Biological sustainability of commercial fishing in the inland waters of Kemptville District. OMNR Technical Paper, OMNR, Kemptville

Carrière M-A, Bulté G, Blouin-Demers G (2009) Spatial ecology of northern map turtles (Graptemys geographica) in a lotic and a lentic habitat. J Herpetol 43:597-604

Chaloupka M, Parker D, Balazs G (2004) Modelling post-release mortality of loggerhead sea turtles exposed to the Hawaii-based pelagic longline fishery. Mar Ecol Prog Ser $280: 285-293$

Chopin FS, Arimoto T (1995) The condition of fish escaping from fishing gears - a review. Fish Res 21:315-327

Colotelo AH, Raby GD, Hasler CT, Haxton TJ, Smokorowski KE, Blouin-Demers G, Cooke SJ (2013) Northern pike bycatch in an inland commercial hoop net fishery: Effects of water temperature and net tending frequency on injury, physiology, and survival. Fish Res 137:41-49 
Congdon JD, Dunham AE, Van Loben Sels RC (1993) Delayed sexual maturity and demographics of Blanding's turtles (Emydoidea blandingii): Implications for conservation and management of long-lived organisms. Conserv Biol 7:826-833

Congdon JD, Dunham AE, Van Loben Sels RC (1994) Demographics of common snapping turtles (Chelydra serpentine): implications for conservation and management of long-lived organisms. Am Zool 34:397-408

Cooke SJ (2008) Biotelemetry and biologging in endangered species research and animal conservation: relevance to regional, national and IUCN Red List threat assessments. Endang Species Res 4:165-185

Cooke SJ, O’Connor CM (2010) Making conservation physiology relevant to policy makers and conservation practitioners. Conserv Lett 3:159-166

Cooke SJ, Hinch SG, Wikelski M, Andrews RD, Wolcott TG, Butler PJ (2004) Biotelemetry: a mechanistic approach to ecology. Trends Ecol Evol 19:334-343

Cooke SJ, Sack L, Franklin CE, Farrell AP, Beardall J, Wikelski M, Chown SL. (in press a) What is conservation physiology? Perspectives on an increasingly integrated and essential science. Conserv Phys 00:000-000

Cooke SJ, Donaldson MR, O'Connor CM, Raby GD, Arlinghaus R, Danylchuk AJ, Hanson KC, Hinch SG, Clark TD, Patterson DA, Suski CD (In press b) The physiological consequences of catch-and-release angling: perspectives on experimental design, interpretation, extrapolation, and relevance to stakeholders. Fisheries Manag Ecol 00:000-000 
Crowder LB, Murawski SA (1998) Fisheries bycatch: implications for management. Fisheries 23:8-17

Davis MW (2002) Key principles for understanding fish bycatch discard mortality. Can J Fish Aquat Sci 59:1834-1843

Davis MW (2007) Simulated fishing experiments for predicting delayed mortality rates using reflex impairment in restrained fish. ICES J Mar Sci 64:1535-1542

Davis MW (2010) Fish stress and mortality can be predicted using reflex impairment. Fish Fish 11:1-11

Davis MW, Parker SJ (2004) fish size and exposure to air: potential effects on behavioural impairment and mortality rates in discarded sablefish. N Am J Fish Manage 24:518-524

Davis MW, Olla BL, Schreck CB (2001) Stress induced by hooking, net towing, elevated sea water temperature, and air in sablefish: lack of concordance between mortality and physiological measures of stress. J Fish Biol 58:1-15

Dejours P (1994) Environmental factors as determinants in bimodal breathing: an introductory overview. Amer Zool 34:178-183

Diggles BK, Cooke SJ, Rose JD, Sawynok W (2011) Ecology and welfare of aquatic animals in wild capture fisheries. Rev Fish Biol Fisheries 21:739-765

Donaldson MR, Arlinghaus R, Hanson KC, Cooke SJ (2008) Enhancing catch-andrelease science with biotelemetry. Fish Fish 9:79-105 
Dudgeon D, Arthington AH, Gessner MO, Kawabata Z-I, Knowler DJ, Lévêque C, Naiman RJ, Prieur-Richard A-H, Soto D, Stiassny MLJ, Sullivan CA (2006) Freshwater biodiversity: importance, threats, status and conservation challenges. Biol Rev 81:163-182

Echwikhi K, Jribi I, Bradai MN, Bouain A (2010) Gillnet fishery - loggerhead turtle interactions in the Gulf of Gabes, Tunisia. Herpetol J 20:25-30

Ernst CH, Lovich JE, Barbour RW (1994) Turtles of the United States and Canada. Smithsonian Institution Press: Washington pp 578

[FAO] Food and Agriculture Organization (2009) The State of World Fisheries and Aquaculture 2008. FAO Fisheries and Aquaculture Department.

Feder ME, Burggren WW (1985) Cutaneous gas exchange in vertebrates: design, patterns, control and implications. Biol Rev Cambridge Philos Soc 60:1-45

Finkbeiner EM, Wallace BP, Moore JE, Lewison RL, Crowder LB, Read AJ (2011) Cumulative estimates of sea turtle bycatch and mortality in USA fisheries between 1990 and 2007. Biol Conserv 144:2719-2727

Frankel HM, Steinberg G, Gordon J (1966) Effects of temperature on blood gases, lactate and pyruvate in turtles, Pseudemyces scripta elegans, in vivo. Comp. Biochem. Physiol. 19:279-283

Fratto ZW, Barko VA, Pitts PR, Sheriff SL, Briggler JT, Sullivan KP, McKeage BL, Johnson TR (2008) Evaluation of turtle exclusion and escapement devices for hoop-nets. J Wildl Manage 72:1628-1633 
Frick LH, Reina RD, Walker TI (2010) Physiological changes and post-release survival of Port Jackson sharks (Heterodontus portusjacksoni) and gummy sharks (Mustelus antarcticus) following gill-net and longline capture in captivity. J Exp Mar Biol Ecol 385:29-37

Galois P, Ouellet M (2007) Traumatic injuries in eastern spiny softshell turtles (Apalone spinifera) due to recreational activities in the northern Lake Champlain basin. Chelonian Conserv Biol 6:288-293

Gatten RE Jr (1981) Anaerobic metabolism in freely diving painted turtles (Chrysemys picta). J Exp Zool 216:377-385

Gatten RE Jr (1984) Aerobic and anaerobic metabolism of freely-diving loggerhead musk turtles (Sternotherus minor). Herpetologica 40:1-7

Gibbons JW, Scott DE, Ryan TJ, Buhlmann KA, Tuberville TD, Metts BS, Greene JL, Mills T, Leiden Y, Poppy S, Winne CT (2000) The global decline of reptiles, déjà vu amphibians. Bioscience 50:653-666

Gleiss AC, Dale JJ, Holland KN, Wilson RP (2010) Accelerating estimates of activityspecific metabolic rate in fishes: testing the applicability of acceleration dataloggers. J Exp Mar Biol Ecol 385:85-91

Hall SJ, Mainprize BM (2005) Managing by-catch and discards: how much progress are we making and how can we do better? Fish Fish 6:134-155

Hall MA, Alverson DL, Metuzals KI (2000) By-catch: problems and solutions. Mar Pollut Bull 41:204-219 
Harms CA, Mallo KM, Ross PM, Segars A (2003) Venous lood gases and lactates of wild loggerhead sea turtles (Caretta caretta) following two capture techniques. J Wildlife Dis 39:366-374

Harrington JM, Myers RA, Rosenberg AA (2005) Wasted fishery resources: discarded by-catch in the USA. Fish Fish 6:350-361

Herbert CV, Jackson DC (1985) Temperature effects on the responses to prolonged submergence in the turtle Chrysemys picta bellii. I. Blood acid-base and ionic changes during and following anoxic submergence. Physiol Zool 58:655-669

Hidalgo-Vila J, Díaz-Paniagua C, Pérez-Santigosa N, Plaza A, Camacho I, Recio F (2007) Hematologic and biochemical reference intervals of free-living Mediterranean pond turtles (Mauremys leprosa). J Wildl Dis 43:798-801

Hoopes LA, Landry Jr. AM, Stabeneau EK (2000) Physiological effects of capturing Kemp's ridley sea turtles, Lepidochelys kempii, in entanglement nets. Can J Zool 78:1941-1947

Jackson DC (2000a) How a turtle's shell helps it survive prolonged anoxic acidosis. Physiol Sci 15:181-185

Jackson DC (2000b) Living without oxygen: lessons from the freshwater turtle. Comp Biochem Physiol A 125:299-315

Jackson DC, H Silverblatt (1974) Respiration and acid-base status of turtles following experimental dives. Am J Physiol 226:903-909 
Jackson DC, Crocker CE, Ultsch GR (2000) Bone and shell contribution to lactic acid buffering of submerged turtles Chrysemys picta bellii at $3^{\circ} \mathrm{C}$. Am J Physiol Regul Integr Comp Physiol 278:1564-1571

Julian F, Beeson M (1998) Estimates of marine mammal, turtle and seabird mortality for 2 California gillnet fisheries: 1990-1995. Fish Bull 96:271-284

Keiver KM, Weinberg J, Hochachka PW (1992a) The effect of anoxic submergence and recovery on circulating levels of catecholamines and corticosterone in the turtle, Chrysemys picta. Gen Comp Endocr 85:308-315

Keiver KM, Weinberg J, Hochachka PW (1992b) Roles of catecholamies and corticosterone during anoxia and recovery at $5^{\circ} \mathrm{C}$ in turtles. Am J Physiol 263: R770-R775

Kelleher K (2005) Discards in the world's marine fisheries: An update. Rome: Food and Agriculture Organisation of the United Nations, FAO

Larocque SL, Colotelo AH, Cooke SJ, Blouin-Demers G, Haxton T, Smokorowski KE (2012a) Seasonal patterns in bycatch composition and mortality associated with a freshwater hoop net fishery. Anim Conserv 15:53-60

Larocque SL, Cooke SJ, Blouin-Demers G (2012b) A breath of fresh air: avoiding anoxia and mortality of freshwater turtles in fyke nets by the use of floats. Aquatic Conserv: Mar Freshw Ecosys 22:198-205 
Larocque SL, Cooke SJ, Blouin-Demers G (2012c) Mitigating bycatch of freshwater turtles in passively fished fyke nets through the use of exclusion and escape modifications. Fish Res 125-126:149-155

LeDain MRK, Larocque SM, Stoot LJ, Cairns NA, Blouin-Demers G, Cooke SJ. (2013) Assisted recovery following prolonged submergence in fishing nets can be beneficial to turtles: an assessment with blood physiology and reflex impairment. Chelonian Conserv Biol In press

Lewison RL, Freeman SA, Crowder LB (2004) Quantifying the effects of fisheries on threatened species: the impact of pelagic longlines on loggerhead and leatherback sea turtles. Ecol Lett 7:221-231

Lewison RL, Nel DC, Taylor F, Croxall JP, Rivera KS (2005) Thinking big-taking a large-scale approach to seabird bycatch. Mar Ornithol 33:1-5

Lowry MB, Pease BC, Graham K, Walford TR (2005) Reducing the mortality of freshwater turtles in commercial fish traps. Aquatic Conserv: Mar Freshw Ecosyst $15: 7-21$

Lutcavage ME, Lutz PL (1991) Voluntary diving metabolism and ventilation in the loggerhead sea turtles. J Exp Mar Biol Ecol 147:287

McClellan CM, Read AJ (2009) Confronting the gauntlet: understanding incidental capture of green turtles through fine-scale movement studies. Endang Species Res $10: 165-179$ 
McClellan CM, Read AJ, Price BA, Cluse, WM, Godfrey MH (2009) Using telemetry to mitigate the bycatch of long-lived marine vertebrates. Ecol Appl 19:1660-1671

Milton SL, Prentice HM (2007) Beyond anoxia: the physiology of metabolic downregulation and recovery in the anoxia-tolerant turtle. Comp Biochem Physiol A $147: 277-290$

Minteer BA, Collins JP (2005) Why we need an "ecological ethics". Front Ecol Environ $3: 332-337$

Moore JE, Zydelis R (2008) Quantifying seabird bycatch: where do we go from here? Anim Conserv 11:257-259

Musacchia XJ (1959) The viability of Chrysemys picta submerged at various temperatures. Physiol Zool 32:47-50

Oliveira-Júnior AA, Tavares-Dias M, Marcon JL (2009) Biochemical and hematological reference ranges for Amazon freshwater turtle, Podocnemis expansa (Reptilia: Pelomedusidae), with morphologic assessment of blood cells. Res Vet Sci 86:146151

Olla BL, Davis MW, Schreck CB (1997) Effects of simulated trawling on sablefish and walleye Pollock: the role of light intensity, net velocity and towing duration. J Fish Biol 50:1181-1194

Putman RJ (1995) Ethical considerations and animal welfare in ecological field studies. Biodivers Conserv 4:903-915 
Raby GD, Colotelo AH, Blouin-Demers G, Cooke SJ (2011) Freshwater commercial bycatch: an understated conservation problem. Bioscience 61:271-280

Reese SA, Crocker CE, Carwile ME, Jackson DC, Ultsch GR (2001) The physiology of hibernation in common map turtles (Graptemys geographica). Comp Biochem Physiol A 130:331-340

Reese SA, Jackson DC, Ultsch GR (2003) Hibernation in freshwater turtles: softshell turtles (Apalone spinifera) are the most intolerant of anoxia among North American species. J Comp Physiol B 173:263-268

Reese SA, Stewart ER, Crocker CE, Jackson DC, Ultsch GR (2004) Geographic variation of the physiological response to overwintering in the painted turtle (Chrysemys picta). Physiol Biochem Zool 77:619-630

Ricciardi A, Rasmussen JB (1999) Extinction rates of North American freshwater fauna. Conserv Biol 13:1220-1222

Robin ED, JW Vester, HV Murdaugh Jr, JE Millen (1964) Prolonged anaerobiosis in a vertebrate: Anaerobic metabolism in the freshwater turtle. J Cell Comp Physiol $63: 287-297$

Rutz C, Hays GC (2009) New frontiers in biologging science. Biol Lett 5:289-292

Ryer CH, Ottmar ML, Strum EA (2004) Behavioral impairment after escape from trawl codends may not be limited to fragile fish species. Fish Res 66:261-269 
Schreck CB, Olla BL, Davis MW (1997) Behavioral responses to stress. In: Iwama GK, Pickering AD, Sumpter JP, Schreck CB (eds) Fish stress and health in aquaculture. Cambridge University Press, New York, p 145-170

Seebacher F, Franklin CE (2012) Determining environmental causes of biological effects: the need for a mechanistic physiological dimension in conservation biology. Phil Trans R Soc B 367:1607-1614

Seidel WR, McVea C Jr. (1982) Development of a sea turtle excluder shrimp trawl for the southeast US penaeid shrimp fisheries. In: Bjorndal KA (ed) Biology and Conservation of Sea Turtles. Smithsonian Institution Press, Washington, DC, p 467-502

Seymour RS (1982) Physiological adaptations to aquatic life. In: Gans C, Pough FH (eds) Biology of the Reptilia Vol:13, Physiology D, Physiological Ecology. Academic Press, London, p 1-51

Shepard ELC, Wilson RP, Quintana F, Laich AG, Liebsch N, Albareda DA, Halsey LG, Gleiss A, Morgan DT, Myers AE, Newman C, Macdonald DW (2008) Identification of animal movement patterns using tri-axial accelerometery. Endang Species Res 10:47-60

Skomal GB (2007) Evaluating the physiological and physical consequences of capture on post-release survivorship in large pelagic fishes. Fisheries Manag Ecol 14:81-89 
Snoddy JE, Landon M, Blanvillain G, Southwood A (2008) Blood biochemistry of sea turtles capture in gillnets in the Lower Cape Fear river, North Carolina, USA. J Wildlife Manage 73:1394-1401

Snoddy JE, Williard A (2010) Movement and post-release mortality of juvenile sea turtles released from gillnets in the lower Cape Fear River, North Carolina, USA. Endang Species Res 12:235-247

Stone PA, Dobie JL, Henry RP (1992) Cutaneous surface area and bimodal respiration in soft-shelled (Trionyx spiniferus), stinkpot (Sternotherus odoratus), and mud turtles (Kinosternon subrubrum). Physiol Zool 65:311-330

Stoot LJ, Cairns NA, Blouin-Demers B, Cooke SJ (2013) Physiological disturbances and behavioural impairment associated with the incidental capture of freshwater turtles in a commercial fyke-net fishery. Endang Species Res In press

Swimmer Y, Arauz R, McCracken M, McNaughton L, Ballestero J, Musyl M, Bigelow K, Brill R (2006) Diving behaviour and delayed mortality of olive ridley sea turtles Lepidochelys olivacea after their release from longline fishing gear. Mar Ecol Prog Ser 323:253-261

Thompson LA, Donaldson MR, Hanson KC, Arlinghaus R, Cooke SJ (2008) Physiology, behavior and survival of angled and air exposed largemouth bass. N Am J Fish Manage 28:1059-1068 
Ultsch GR (1988) Blood gases, hematocrit, plasma ion concentrations, and acid-base status of musk turtles (Sternotherus odoratus) during simulated hibernation. Physiol Zool 61:78-94

Ultsch GR (1989) Ecology and physiology of hibernation and overwintering among freshwater fishes, turtles, and snakes. Biol Rev 64: 435-516

Ultsch GR, Jackson DC (1982) Long-term submergence at $3^{\circ} \mathrm{C}$ of the turtle, Chrysemys picta bellii, in normoxic and severely hypoxic water I. Survival, gas exchange and acid-base status. J Exp Biol 96:1 1-28

Ultsch GR, Herbert CV, Jackson DC (1984) The comparative physiology of diving in North American freshwater turtles. I. Submergence tolerance, gas exchange, and acid-base balance. Physiol Zool 57:620-631

Ultsch GR, Cochran BM (1994) Physiology of northern and southern musk turtles (Sternotherus odoratus) during simulated hibernation. Physiol Zool 67:263-281

Ultsch GR, Jackson DC (1995) Acid-base status and ion balance during simulated hibernation in freshwater turtles from the Northern portions of their ranges. J Exp Zool 293:482-493

Ultsch GR, Carwile ME, Crocker CE, Jackson DC (1999) The physiology of hibernation among painted turtles: The eastern painted turtle Chrysemys picta picta. Physiol Biochem Zool 72:493-501

UN FAO (2009) Guidelines to reduce sea turtle mortality in fishing operations. UN FAO Fisheries Division, Rome 
Wallace BP, Lewison RL, McDonald SL, McDonald RK, Kot CY, Kelez S, Bjorkland R, Finkbeiner EM, Helmbrecht S, Crowder LB (2010) Global patterns of marine turtle bycatch. Conserv Lett 10:131-142

Warren DE, Jackson DC (2004) Effects of swimming on metabolic recovery from anoxia in the painted turtle. J Exp Biol 207:2705:2713

Wikelski M, Cooke SJ (2006) Conservation physiology. Trends Ecol Evol 21:38-46

Wilson RP, Shepard ELC, Liebsch N (2008) Prying into the intimate details of animal lives: use of a daily diary on animals. Endang Species Res 4:123-137

Yoda K, Sato K, Niizuma Y, Kurita M, Bost CA, Le Moho Y, Naito Y (1999) Precise monitoring of porpoising behaviour of Adélie penguins determine using acceleration data loggers. J Exp Biol 202:3121-3126

Zeeberg J, Corten A, de Graaf E (2006) Bycatch and release of pelagic megafauna in industrial trawler fisheries off Northwest Africa. Fish Res 78:186-195 